\title{
The Centipede in the Maya Art and Culture
}

\author{
Monika Ciura
}

\begin{abstract}
Insects and arthropods appear in the Maya art in a rich and diverse context, suggesting their prominent significance in the culture. In the following chapters I present my research concerning the appearance of the centipede, one of the arthropods most commonly represented in the Maya iconography. I studied depictions of the centipede in the art of the Classic Period (250 A.D. - 909 A.D) and compared them with epigraphical and ethnohistorical sources in order to define the specific symbolic meaning of this animal in all contexts of its occurrence. My research focused on the centipede as part of the vision serpent complex, its connections to the Palenque triad, Sun God K'inich Ajaw and Bolon Yokte K'uh. In the conclusion, I try to establish the significance of the centipede as the animal of transition, more specifically the transition between night and day and the Underworld and our world.
\end{abstract}

Keywords: Maya culture, iconography, mythology, cultural entomology, insects, arthropods, centipede

\begin{abstract}
o
EL CIEMPIÉS EN EL ARTE Y LA CULTURA MAYA

Los insectos y artrópodos aparecen en el arte Maya en un contextos ricos y diversos, lo que sugieren su importancia en esta cultura. En los siguientes capítulos, presento mi investigación sobre la aparición del ciempiés, uno de los artrópodos más frecuentemente representados en la iconografía Maya. Estudié representaciones de ciempiés en el arte del Período Clásico (250 A.D. - 909 A.D) y las comparé con los documentos epigráficas y etnohistóricas para definir el significado simbólico específico de este animal en todos los contextos de su aparición. Mi investigación se centró en el ciempiés como parte del complejo de la serpiente de la Visión, sus conexiones con la tríada de Palenque, dios del sol K'inich Ajaw y Bolon Yokte K’uh. En la conclusión, trato de establecer el significado del ciempiés como el animal de transición, más específicamente la transición entre la noche y el día y el inframundo y nuestro mundo.
\end{abstract}

Palabras clave: Cultura maya, iconografía, mitología, entomología cultural, insectos, artrópodos, ciempiés.

Monika Ciura • University of Warsaw, monika.ciura@student.uw.edu.pl, https://orcid.org/0000-0002-0790-9589 
The Ancient Maya lived in the demanding conditions of the tropical forest, they were listening to the gods through the movements of the universe, tracing the stars and celestial bodies. In their highly conceptualized and symbolic art, nature was often presented by using visual metaphors, and religious and cosmological concepts could have zoomorphic features. The soul permeating the world was considered gaseous, air-like and compared to the breath and wind.

The spiritual, supernatural realm and the environment were overlapping as dimensions of forces over which people had limited control. Aspects of nature were given a divine status and they constituted a significant part of the perception of the gods and their powers. The divisions between the mythical, natural and human spheres were not clearly distinguished, and gods, people, animals, celestial or atmospheric phenomena and even objects were all connected, as the main forces shaping the world.

The understanding of the significance of the concrete species of animals in the Maya worldview is complemented by their appearance in art, that reveals their role as the gods' and people's companions and the actors in events related both to ritual and every-day life. Most of the animal representations belong to the way symbolic and iconographic complex, which comprises the anthropomorphic fauna engaged with the practices connected with magic, usually linked to the modern beliefs concerning spirit companions, called nagualism. However, the nagualism from the ethnohistorical sources does not fit the ancient Maya worldview. In the modern system, it is a real animal, a companion spirit, who shares the destiny with a human and might be used in shamanistic practices, while during the Classic Period, way concept was based on zoomorphic, but in general hybrid forms of the creatures that were linked with the people, gods, dynasties and even places. Finally, it is important to underline, that the way concept was generally concerning the dangerous and dark powers and was closely connected with sacrifice, blood and death. The system of beliefs based on the close connection between humans and animals is also present in Siberia and among Indian cultures and it is called perspectivism - the worldview based not on the concept of one nature and many cultures, but proposing the reverse vision - many natures and one culture in societies where people and their environment form one culture, and differ only in physical form (Viveiros de Castro 1992). Hence, also the conversion of perspectives and identity between humans and animals, when there is no quality gap between them. Similar attitude seems to be shared by the ancient Maya, since their link with animals or more generally animallike creatures, seems very intimate.

The following article is part of my research concerning the context of the insects' and arthropods' appearance in the Maya art. The insects' place in the worldviews and religions of different cultures gives an interesting insight into how the smallest creatures can make an impact on human development and society. The mythological entries concerning insects in general, explain their behavior, traits or present them as engaged in the events concerning the creation of specific aspects 
of the world. There were cultures, where one insect was especially esteemed, like the scarab in Egypt - the symbol of rebirth or cicada in China, which had similar symbolism. There are also cultures, which give the insects in general a prominent place in the mythology and art, like the Australian aborigines, who have 30 insect totems or Indians of the Southwest America, who depicted insects on vase paintings (Capinera 1993).

As we gain a broad knowledge of the insects' place in the culture of living societies, it is more difficult to understand it only from the archeological record. The main carrier for the ancient thought is art, therefore I chose to study the appearance of the insects and arthropods in the Maya art to see how these small, sometimes dangerous, sometimes useful animals were used to build mythology, symbolism and ritual. One of the arthropods was especially widespread in the art and inscriptions from the Classic Period - the centipede appears in different contexts connected to the mythological narrative and this animal's features were incorporated into the composition of fantastic creatures and became the basis of important concepts like the vision quest or the entrance to the Underworld.

\section{Anatomy, taxonomy and biology of the centipede}

Centipede is a common name for the arthropod belonging to the class of Chilopoda and more specifically to the genus Scolopendra. There are 87 species of centipedes living in Central America and over 3000 species all over the world, and they are one of the oldest terrestrial arthropods, living for over 300 million years. The English word "centipede" is derived from Latin - centi - "hundred" and pes/pedes - "foot", similar etymology has a Spanish word "ciempies". The genus Scolopendra is the most venomous and largest of the Chilopoda class, however the classification of species and their distinction is not easy and seems far from being completed (Hogue 1991). I will be using the general term centipede both in this part and the part concerning the Maya art, as the general term for venomous, segmented arthropods. Centipede has only one pair of legs for each segment (except the hindmost one), the segments are clearly distinct, and the pairs of legs are always in odd numbers, therefore the existence of the centipede with one hundred legs is impossible. The venom is applicate through the fangs called forcipules - modified from the first pair of legs, which contain venom glands and form one of two pairs of maxillae.

Most of the centipedes are small and reach several centimeters, however some species of Scolopendra are quite long, the Scolopendra gigantea can measure up to $27 \mathrm{~cm}$ and Scolopendra heros can reach over $20 \mathrm{~cm}$. In literature concerning Maya iconography, there are sometimes mentions of the Scolopendra gigantea as the species depicted in art, this one however does not exist in Central America.

Centipedes live worldwide in various, but usually rather hot environments, and they are most abundant in tropical forests. They emerge as the sun goes down and prey on vertebrates and insects. The venom from a single centipede contains 
over 500 proteins and peptides, mainly acetylcholine, histamine and serotonin and is dangerous for small animals, causing intense local inflammation, persistent edema and tissue damage, which may lead to the death of the animal. The bite of the centipede is not a major threat for a human, however there were cases of children's death caused by it. The symptoms of the bite are "severe pain, local pruritus, headache, nausea, vomiting, anxiety, palpitation, local tissue swelling, erythema, necrosis, lymph node swelling, ischemia and rhabdomyolysis" (Jarrar Bashir 2010: 19). The pain usually last from several hours to a couple of days.

\section{Centipedes in art and epigraphy of the Classic Period - the general overview}

The word for centipede in some of the modern Maya languages is chapat or chapaht (Kettunen, Davis 2004: 26, Table 4.1.). In the Classic Maya script, there is a logogram depicting a skeletal head with two protruding and slightly hooked fangs, which corresponds with the iconographic features of the centipede, and its spelling is CHAPAT. The logogram comes with various phonetic complements: CHAPATtu, cha-CHAPAT-ti; the word appears also in phonetic spelling - cha-pa-ta on vase K1256. Different $\mathrm{t}$-vowel suffixes imply some possible disharmonic spelling chapaat, chapaa[h]t, chapa't, chapa'[h]t, while the phonetic spelling from vase K1256 is simply harmonic - chapat/chapa[h]t (Kettunen, Davis 2004: 33). The etymology of the root chap is not certain - "Lacadena and Wichmann (n.d.) reconstructed the form *chapa'ht for the Classic period, in which they identified the root as chap "to coil" and -at as a-Vt nominalizing suffix" (Boot 2009: 254) but Eric Boot also proposed another possibility: "I interpret chap to be a transitive verb root chap(a) with the meaning "to cook, to boil" (Chol, Cholti', Chorti') and -at as a-Vt nominalizing suffix. Originally thus chapat may have meant "cooker, boiler," a meaning close to for example Tojolabial k'ak'chan "fire serpent" and the Chol entry chäk xjochoch "red rattle snake" ("red" as color of fire) (Boot 2009: 278).

Table. 1.1. Dictionary entries - centipede

\begin{tabular}{|l|l|l|}
\hline Mopan & Chupaat & Ciempies (Kaufman 2003: 660) \\
\hline Ch'oltí & Chapaht & çientopies (Boot 2004:18) \\
\hline
\end{tabular}

The CHAPAT in the inscriptions appears in two main contexts - as the sak baak nah chapat - the name of a way creature, and Wuk Chapat Tzikin K'inich Ajaw - the name of the god with solar aspects - K'inich Ajaw. The sak baak nah chapat is usually translated as "white bone house centipede", but other translations are possible, albeit less probable. The sak baak could mean "force, vigour, strength of body" (Barrera Vásquez 1993: 710). The nah on the other hand stands also for "first" and "big" (Boot 2009: 134). Considering these possibilities, the whole name phrase of this creature could metaphorically bind the meanings of homophonous words. 
The "white bone" translation, however, is common because it matches the iconographic traits of the centipede, most often depicted with a bony, skeletal maw.

Chapat word for centipede was incorporated also in the names of the kings. Four rulers of Tonina were named after this animal, that is K'inich Bahlam Chapat - "Radiant Jaguar Centipede", K’inich 'Ichaak Chapat - "Radiant Claw Centipede", K'inich Tuun Chapat - "Radiant Stone Centipede and 'Uh Chapat. This indicates that the centipede was an important, probably deified creature linked to the dynasty of Tonina.

There is also another sign connected graphically with the centipede, that is T769a, representing two fangs embedded in a boney maw, being the logogram for WAY, homophonous to the T539 WAY sign. The meaning of the T769a, however, is different; it "represents $a<$ hole $>$ or supernatural portal and the jaws of the $<$ Snaggle Tooth Dragon>" (Montgomery, Helmke 2007)" and could mean "hole, entrance, room, water" (Mongomery, Helmke 2007). This sign is usually incorporated in the word wayhaab - the name of the last month of the year.

An interesting case of the sign with two centipede's fangs depicted from the side also occurs in the script. This kind of logogram appears in the Early Classic Emblem Glyph of El Peru, and its phonetic value could be WAK, on the basis of later examples of this Emblem Glyph with the syllabic spelling wa- $k a$ (Gunter 2007). The same sign appears on Stela A from Copan, this time as a syllable wa. In glyph block A11, there is syllabic spelling of the word wawaan - wa-awa-ni - meaning "to erect" (Fig.1.1.). The meaning of the word wak is unknown, but it could have been the name for the centipede's maw or fangs (Guenter 2007).

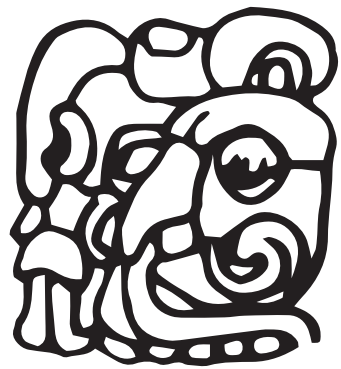

Fig.1.1.

The centipede headdress appears as an additional feature or component of the other signs. The Akan logogram is a good example. The human head with black area around the eyes and the percentage sign on the cheek representing the death god Akan is topped by the upper maw of a centipede with two fangs. This kind of sign appears on the Tikal Lintel 3 from Temple 4 (glyph blocks E6 and G3). This association of the centipede with a deity belonging to the death gods complex is suggestive, especially when it comes to Akan, who, like the centipede, is introduced as a way character. The Underworld connotations of this arthropod are clearly underlined.

The iconographic traits of the centipede were not immediately recognized, as they were first considered as snake ones. The existence of a skeletal being among the iconographic complex of serpents was described as a version of a snake, an animal widely represented in Maya art (Freidel, Schele, Parker 1993). In 2003, Karl Taube described the iconographical corpus of skeletal beings as centipedes, giving them quite a prominent place in Maya imagery. The characteristic features of the centipedes in the Maya art are: segmented body often with the corresponding 


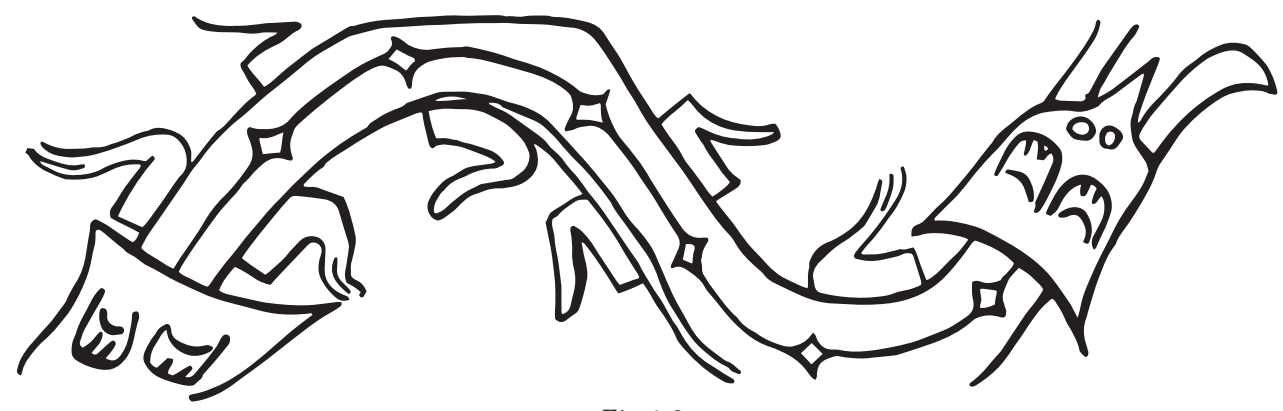

Fig.1.2.

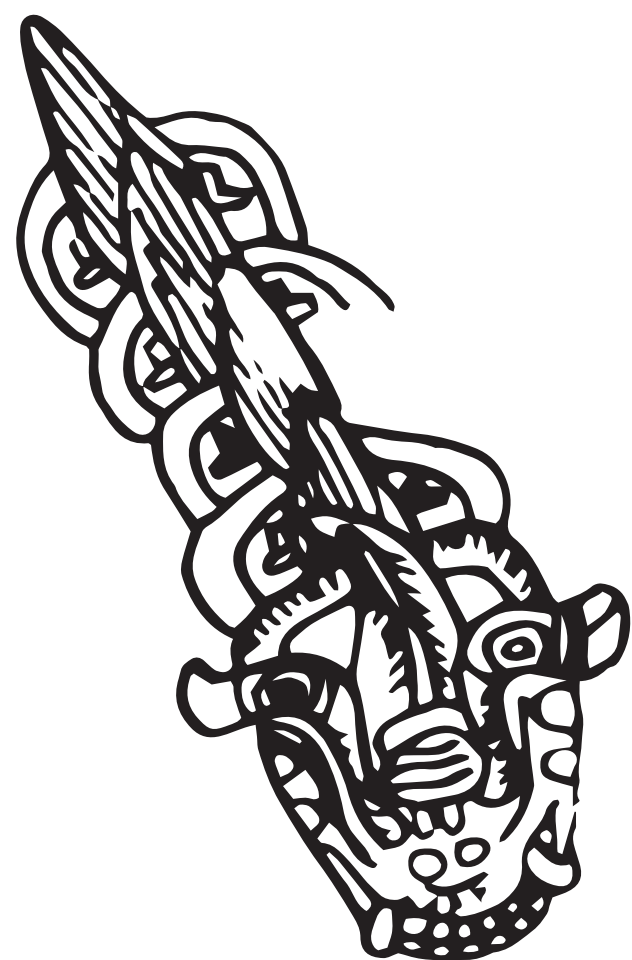

Fig.1.3.

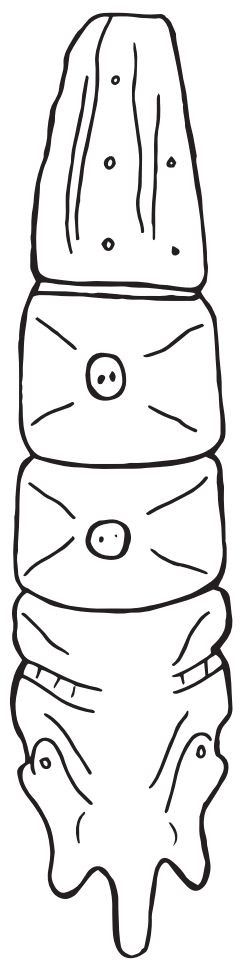

Fig.1.4.

amount of legs and a "trifoil" mouth with two fangs firmly protruding from the maw, which usually has dot markings characteristic of the representations of bones. Usually the death eyes are attached to its body and to the maw. The death eyes motif sometimes is conflated with the black water motif - three black circles imitating droplets of water. Both of these features indicate the dark, watery Underworld as the place of existence of the centipede or centipede-like creature. The centipede was already appearing in a quite realistic form in ceramic paintings in the Early Formative Period - the first known representation is from a vessel from Las Bocas, K1608 (Taube 2003: 406, Fig.1.2). Here, the centipede is bicephalic, reflecting the 
manner in which most serpents and serpent-like creatures were represented in the Mesoamerican art. It has four to five legs on each side of the body and is depicted in a specific manner of movement. We can see more detailed images on the Olmec carved jade (K3259 - Fig.1.3.) and the Preclassic Maya carved bone from Chiapa de Corzo (Fig.1.4.), recognized by Taube as depictions of centipedes because of the characteristic segmented body (Taube, 2003: 407). There are only a few Maya ceramic paintings involving the centipede as a more or less realistic animal - one is on vase K7127, where two centipedes are represented under the bar on which two birds are standing - this image seems to be marking the spheres of the Universe the birds are symbols of the sky and the centipedes are symbols of the Earth or the Underworld. On vase K5041, the segmented body of this arthropod is encircling the vessel, creating a simple iconographic motif. Rest of the images of the creatures with the features of the centipede show a bony, skeletal animal with few or more fantastical elements. The characteristic feature of these creatures, pointing to their identification as centipedes, is the maw with two fangs being the extension of it - this manner of depicting the maws differentiates the arthropod from the snake, whose fangs are always embedded inside the maw. The contexts of the appearance of the skeletal centipede's images also imply the supernatural motif of those representations in art and will be closely examined in next chapters.

\section{Chapat as way creature - sak baak nah chapat in Palenque texts}

One exceptionally interesting and unique case, where the whole, bicephalic centipede is represented in the ceramic corpus, is on vase K1256 (Fig.1.5.), where the animal is introduced as a way creature. In a written caption, there is the name of the animal, spelled - cha-pa-ta - chapat, meaning "centipede" and a descriptive part sak baak nah, meaning "white bone house" or "white bone first". The creature is introduced as uway of Bakel - the name of Palenque. In this painting, representing a group of way creatures, there is a man bound by the body of a centipede covered with death eyes, he is also wearing a headdress with the centipede maw. He might be the owner of the way, impersonating it or connecting with it in some way. The other characters depicted on that vase represent a diversified group including a death god with a human head in his hands, a man in a black circle, a man in flames, a man surrounded by two fish, also with a head in his hands, a jaguar and a deer-snake. Concerning the presence of the centipede on the vases depicting way characters or way impersonators, there are also two cases where the jaguar way has centipede fangs- on vase K8606 (Fig.1.6.) and on vase K533, where the lord wears a costume of the jaguar-centipede. The combination of the jaguar and the centipede appears likewise in the aforementioned name of the Tonina ruler - K'inich Bahlam Chapat. It was common to mix the features of different animals in one way creature, and the centipede appears to be the animal fitting the concept of deathly and dangerous co-essences. 


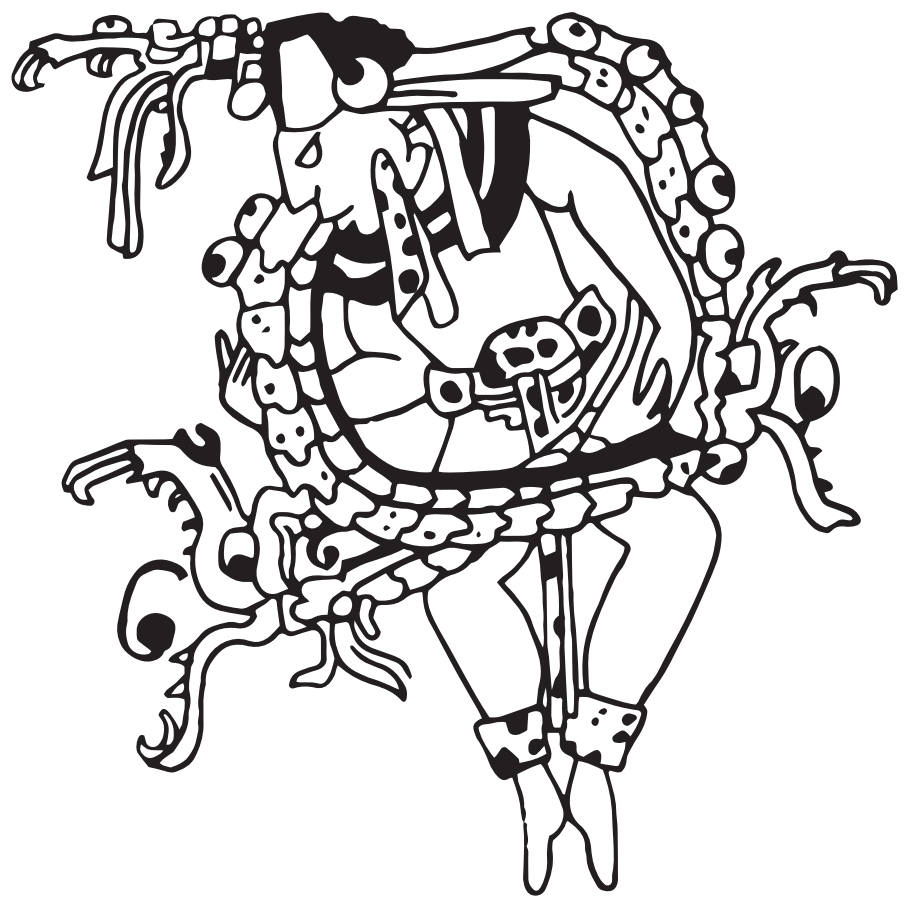

Fig.1.5.

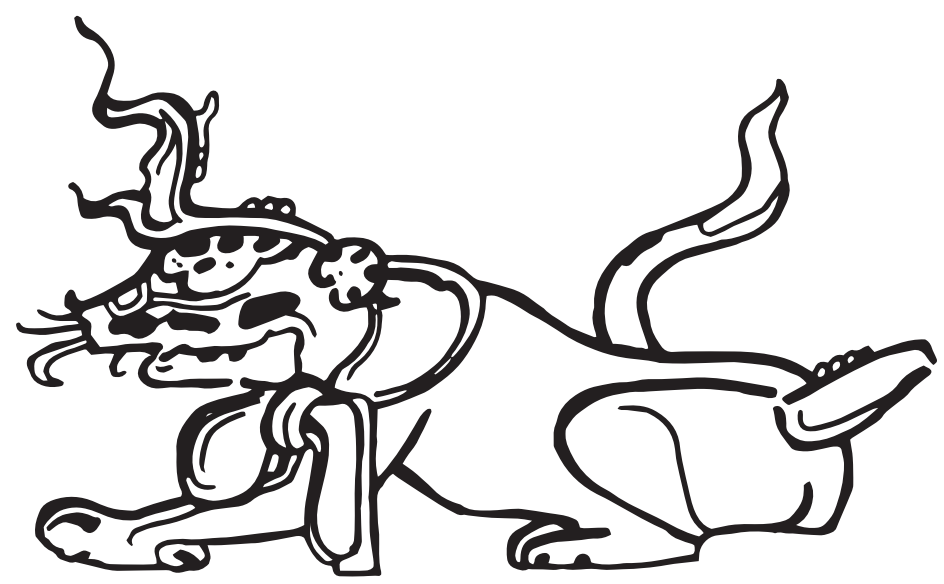

Fig.1.6.

The sak baak nah chapat appears in one of the most important and famous inscriptions in Palenque. On the Tablet from the Temple of the Sun, chapat is part of a long name phrase of GIII - patron god of Palenque (Fig.1.7.). GIII was the middle one from the Palenque Triad and was recognized as the god with the solar aspect, mainly because of the K'inich - "Radiant/ sun -eyed" part in his name. The youngest of the Palenque Triad was GII - the infant aspect of K'awiil, sometimes named 
Unen K'awiil - baby K'awiil. The most important and the oldest was GI, who was supposed to be connected with Venus and also with the Sun because of the "k'in bowl" headdress (Stuart 2005: 166). Each of the gods had a temple dedicated to them - The GI - Temple of Cross and GII - Temple of Foliated Cross. The Temple of the Sun was dedicated to GIII and on the inscribed panel, there is a mention of his mythical birth on October 25th, 2360 B.C and one of his names given there is $t z a^{\prime} t z^{\prime}$ nah sak baak nah chapat. The first part - $t z a^{\prime} t z$ nah was translated by Elisabeth Wagner, Sven Gronemeyer and Christian Prager as the "wet/moist house", and this is an adequate description of the places where the centipedes actually live (Wagner, Gronemeyer, Prager 2015). The "wet house, white bone house" could have been the description of the centipede, by the specification of its place of living. It might have been a mythical place, most likely some Underworld location. There are also interpretations considering the existence of the white bone house in reality (Taube 2003, Wagner, Gronemeyer, Prager 2015:10). The existence of the white bone structure in the real topography of the site doesn't however exclude that it could also be the name of the mythical location, which could be invoked and recreated in real space.

The sak baak nah chapat appears also in another text from Palenque. On the Tablet from Temple XIV, this name is mentioned two times as the name of the way of K'awiil. Here, the connection between God $\mathrm{K}$ and the centipede situates the animal within the vision serpent/way context. The text from Temple XIV describes the mythological event taking place on a date 13 Ok 18 Wo 14.2.5.6.4.11.10, that is on July $29^{\text {th }} 931449$ BC (Eberl, Prager 2005, Fig.1.8.). The verb connected to the name of the K'awiil's way is compiled from number 9 - bolon, and then the syllables i-pi-na-ja, which can be transcribed as bolon ipnaj and translated as "9 times was strengthened". The rare verb ipnaj seems to be a passive form of the root ip-i - "take for strength" (Gronemeyer, MacLeod 2010: 48). The event described using this

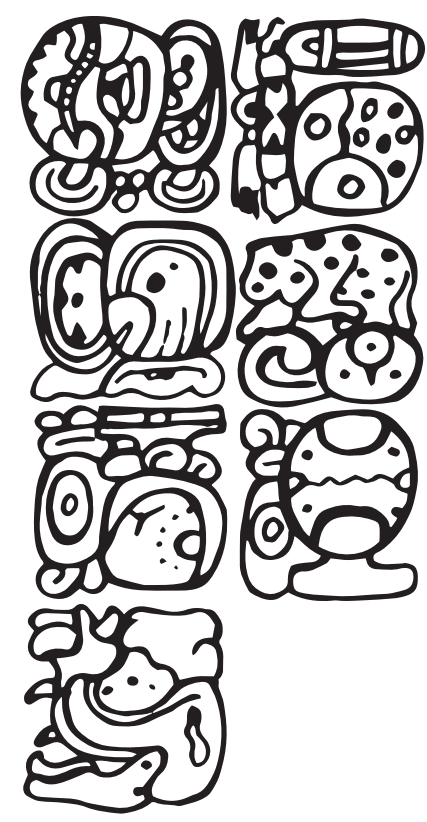

Fig.1.7.

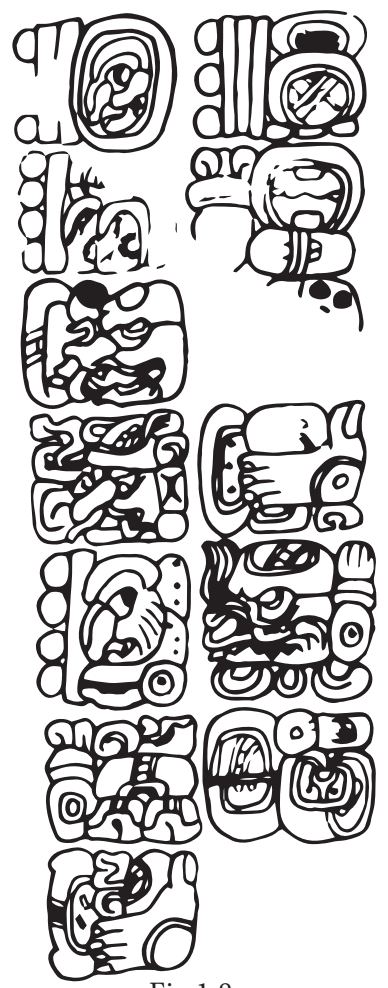

Fig.1.8. 
verb appears twice on the Tablet from Temple XIV - in the main passage and in the secondary text. In the main passage, the text is followed by the name of a way - sak baak nah chapat (uway) Kawiil. Then there is a second verb - u-CH'AM-wa - uchamaw meaning "he grabs/takes/receives it", the object is not present here and the subject is 9 [bolon]-OK-TE'-K'UH, Bolon Yokte' Kuh, another mysterious divine being. The CH'AM verb appears in the other part of this inscription with the K'awiil as the object (CH'AM-KAWIIL) and it is a common verb for the accession statement describing the taking of K'awiil scepter, and this event is presented also in the iconography of the Panel from Temple XIV. The text involving the Sak baak nah chapat and Bolon Yokte' might be a reference to some mythical accession of the latter one, associated with the receiving the K'awiil in the form of his way - nine time strengthened, white bone house centipede. Afterwards in that phrase, there is the Anterior Date Indicator utiiy "it had happened" and the toponym beginning with SAK "white" and ending with NAL - "place". The reading of the main logogram was suggested by Christian Prager as asu or asul - referring to the "large, flying insect like a locust", therefore the whole toponym would mean "White Locust Place" (Prager 2011). Next to it, there is a verb i-PAT-la-ja, ipatlaj, in a positional form, meaning "and then, he/she/it forms/builds", and then there is a noun, which should be the subject - YAX-CH'AM-KAWIIL - yax cham Kawiil - "the first grabbing of Kawiil." This, again, is a reference to the accession rite, this time additionally described as the first one, formed thousands of years before the inscription was made. The whole caption therefore would likely be the mention of the first accession of Bolon Yokte' Kuh through the power of the centipede way of K'awiil - moreover, this accession

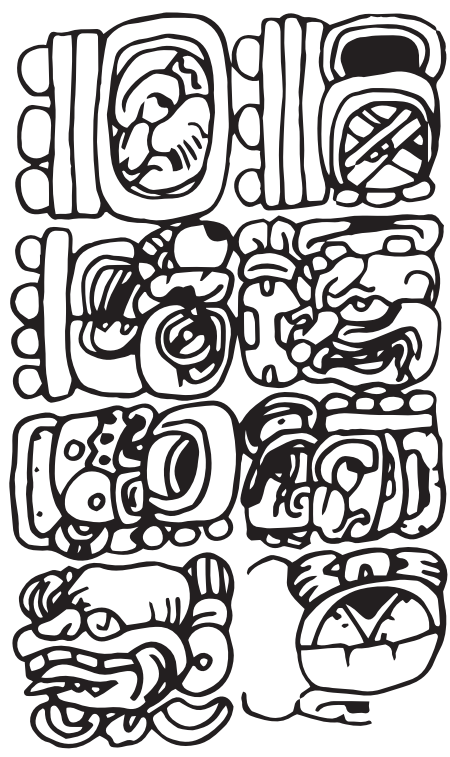

Fig.1.9. seems to be an important reference to the scene depicted on the Panel.

The secondary text referring to the same event is slightly different, as it introduces Bolon Yokte' Kuh as the supervisor of the nine times strengthening of chapat as the way of K'awiil in a phrase - u-K'AB-ji-ya 9[bolon]-OK-TE'-K'UHuka'bjiiy Bolon Yokte' K'uh - "he supervised it Bolon Yok Te’ K'uh" (Fig.1.9.).

The iconography of the Panel is quite as mysterious as the accompanying inscription. The image shows the king K'inich Kan Bahlam II receiving a small, sitting figure of K'awiil from a woman, probably his mother. They are both standing on the water band, symbol of the watery entrance to the Underworld, and the location is given by three glyphs located under the bar, one of which is SAK-ASU-NAL, the same one mentioned before as the place of forming of the first grabbing 
of Kawiil, which seems to be some mythical place. The scene is considered as the resurrection of K'inich Bahlam II, happening on 9.13.13.15.0 9 Ajaw 3 Kankin, two and a half years after his death, which corresponds with the date 5 November 705 . The resurrection is supposed to have some similarities with the accession, as the phrase cham K'awiil is mentioned three times in the inscription. The reference to the mythological event involving sak baak nah chapat and Bolon Yokte' Kuh seems to reinforce this moment of transition as well as the power of K'inich Kan Bahlam. I would say, that this time, it is not only the royal power but also a divine one, as the king has some features of GIII. This is a moment, when the king has completed his journey through the Underworld and becomes a divine being reconnected with the heavenly gods and the patrons of his city. The mentioning of the centipede way of K'awiil is meaningful because of its association with GIII, and also the power of transition, which the whole serpent complex connected with God $\mathrm{K}$ is supposed to have. The character of Bolon Yokte' Kuh is still quite ambiguous, as he is considered the GI (Coe, Kerr 1997), the Night Sun (Zender, Guenter 2003) and the God L "an Underworld god of wealth, warfare, conflict and sacrifice" (Grofe 2009: 15). The Bolon Yokte' Kuh certainly makes an appearance in the context of war and period endings, such as on the 13.0.0.0.0 4 Ajaw 8 Cumku (Zender, Guenter 2003: 104). $\mathrm{He}$ is also mentioned in the context of the ending of $13^{\text {th }}$ baktun prophecy on Tortugero Monument 6. There, the Bolon Yokte' is supposed to be displayed in the great investiture (Gronemeyer, MacLeod 2010: 8) on 4 Ajaw 3 Kankin. The inscription from the Tortugero Monument 6 is also interesting because of the appearance of the verb 9-IP-na-ja - bolon ipnaj in the sentence concerning the war and destruction of the army of Ux Bahlam Joy Chan Ajaw by the local ruler Bahlam Ajaw K'uhul Bakel Ajaw. After the quite poetic verses describing the crushing defeat ("blood became lake, skulls became mountains"), the verb ipnaj appears- "nine times were strengthen", and the object is u-SAK-BAK-IK'-li, if the reading of the sign T533 is baak (Gronemeyer, MacLeod 2010: 49). Again, the verb ipnaj is associated with the number nine and the expression sak baak, here sak baak ikil could mean "white bone breath", but another translation is preferred, referring to the meaning of sak baak as the "force" - "force and breath".

What is the most striking, is the description of the mythological event happening on 13 Ok 18 Wo on the "Regal Rabbit Vase", also in association with Bolon Yokte' K'uh. However, binding of these two narratives is confusing, mainly because of the diversity of the interpretations concerning the text on the vase. Let's take a look at the imagery: there are two scenes - one shows a rabbit standing on the throne and holding the owl hat belonging to the old God L, and the robbed god is standing in front of the animal making gestures of respect and asking him about his garment. The rabbit, however is not cooperative and just swears at him in the exceptional quote of ancient Maya humor -- pu-lu a'-JOL u-tz' Au a-wi-tzi k'u-li-si ?ATti, pulu 'a-jo'l 'uhtz'u 'aw-itz k'uulis Pah-'aat, meaning "burn your head, smell your urine, penis" (Beliaev, Davletshin 2006: 25). The second scene shows the God L in 
front of a deity called the Night Sun, because he has k'in signs on his body, but also $a k^{\prime} b a l$ "darkness" signs on his headdress, whose frontal part resembles the upper jaw of the centipede with a dead eye hanging on the edge. The old god is complaining about his stolen property and the Night Sun is calming him, saying that his garment was retrieved, but the rabbit is just hiding behind his back, so it seems that it was a plot by the animal and the Night Sun, aiming to humiliate the God L. The rabbit in Maya art and mythology was associated with the Moon and Moon Goddess, his headdress in that scene is a representation of the moon disc, so it seems that the two supernatural beings of the night are allies in that matter. One of the columns separating the two scenes contains a widely discussed text describing the events on the day $13 \mathrm{Ok} 18 \mathrm{Wo}$ - after the calendar round comes the phrase he - [wa] (recognized by Grofe 2009) or the deer head variant of k'in sign (Hull, Carrasco, Wald, 2009), then there is ni- CHAM-wa ni-kuy? [OWL HAT] yi-ta 9 [bolon] -OK-TE' K'UH u-ti- ya SAK -'a -su NAL HO- NIK-TE', ni-chamaw ni-kuy y-ita B'olo'n 'Okte'-K'uh 'uhtiiy Sak a'-Sunal-Ho'-Nikte', which could be translated as "? I grab/take it, my owl hat, in the company of Bolon Yokte' K'uh, it happened in Sak-'A'snal Ho'-Nikte" (Beliaev, Davletshin 2006: 24), also the first part is translated as "? I grab/take it, my owl hat, the companion of Bolon Yokte' K'uh" (Grofe 2009). The main controversy is, who is speaking those words, and who is whose companion. I would rather concur with the explanation of Beliaev and Davletshin, that the God L is speaking about his hat, that he took to the place Sak A'snal and Bolon Yokte' Kuh was his companion. It seems that on the date $13 \mathrm{Ok} 18 \mathrm{Wo}$, something was going on in Sak A'snal that required God L taking his owl hat in the company of Bolon Yokte' Kuh and that the event later led to the theft of God L's headdress. If this interpretation is correct, the whole story would be, that on this day, in Sak Asnal - some Underworld, mythical location, there was an event of first accession of Bolon Yokte' K'uh, connected with the nine times strengthening of the white bone house centipede, and that God L was also there with his owl hat. The sak baak nah chapat could have been some form of K'awiil scepter, the utility of power worthy of a god of transition and war. There might also be another explanation, if we consider sak baak nah chapat as the manifestation of GIII, Bolon Yokte' Kuh as the manifestation of GI and GII as the aspect of K'awiil, the event could bring the whole Palenque Triad together even before their birth described on the Panels from the Temple of Cross, Foliated Cross and the Sun. As it was mentioned before, sak baak nah chapat was introduced directly as way of Bakel and way of K'awiil and it seems that the name of a way creature was originally the name of a way of Kawiil and the name of GIII, since it was given in a mention of his birth. The concept of co-essence of royal Palenque's dynasty was therefore related to the patron god of the royal power and the patron god of the city. In the birth statement on the Tablet of the Sun, the GIII is also addressed as k'inich taj wayaab' - "Radiant Torch Dreamer", so he has the powers and abilities that way gives. After the wayaab" title, comes another name - k'in ta [h] bolay - "sun stomach jaguar", again this name appears as the name of a way being in the ceramic corpus (Grube, Nahm 1994). Is it possible that the sun stomach jaguar and white bone house cen- 

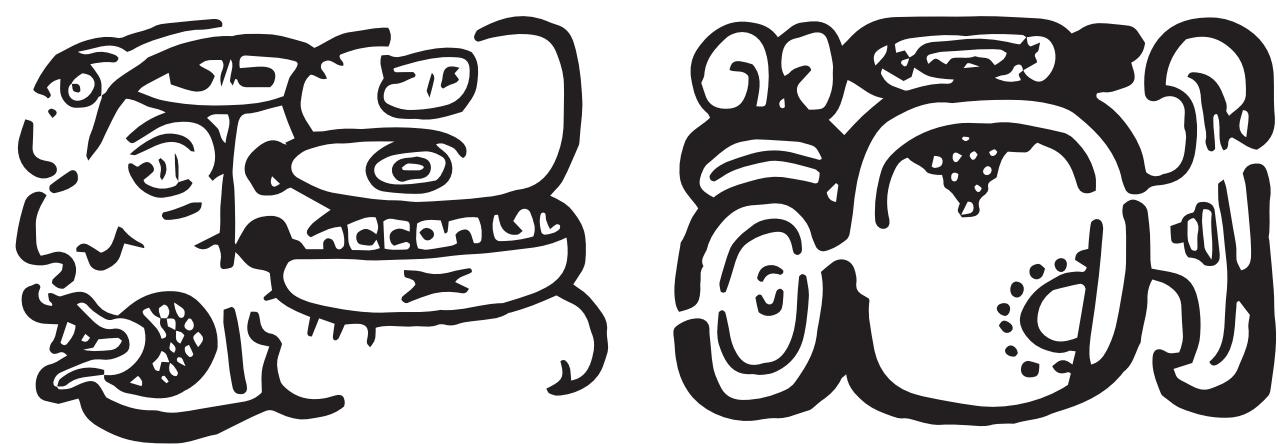

Fig.1.10.

tipede were co-essences, wayob of GIII? Maybe the tzatz nah sak baak nah chapat was the first co-essence, power of the god, that was later transferred into the royal house of Palenque. If we consider the solar aspect of the GIII, it is not surprising that he is associated with the centipede. As it will be explained later, the K'inich Ajaw, Sun God, also seems to be connected to this animal, as well as K'awiil. The sak baak nah chapat entity was defi-

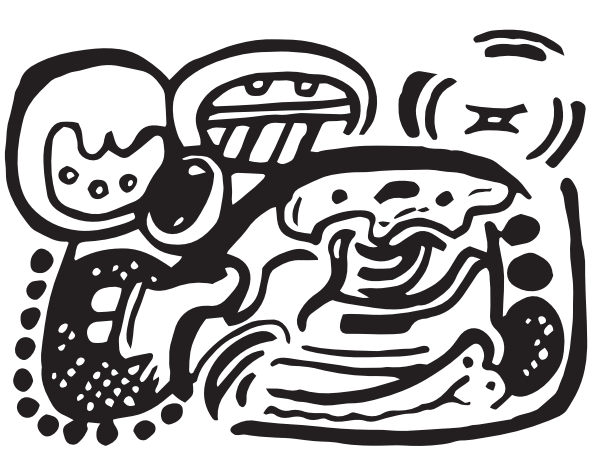

Fig.1.11. nitely important in Palenque, and its royal house gained power from its connections to GIII and Kawiil. The name of the being seems to contain concepts of great importance for the Palenque rulers, the sak nah - "white house", more specifically sak nuk nah, was the name of a royal house mentioned several times in the context of accession in a phrase uchum balam tzam sak nuk nah - "his seat was the jaguar throne in a white big building" on Tablet of 96 Glyphs (Fig.1.10). The word bak/baak - "bone" in the Classic Period comprised the name of the city baak-le - baakel, as it was introduced on vase K1256. Actually, the version of the Bakel Emblem Glyph from the Tablet of 96 Glyph seems to look a little bit like a centipede - it has a bony maw and something that could be fangs in front of it, also the dead eye on the forehead, which could be spelled as a syllable "cha", is present, though the ear part with three black dots looks different (Fig.1.11.). Taking all of this into consideration, the emic understanding of the sak baak nah chapat could be the "centipede from the royal house of Bakel (Palenque)".

\section{Centipede as way of K'awiil}

The bicephalic centipede appears several times in the scenes of "conjuring" supernatural beings, in the context in which the snake ("vision serpent", "vision dragon") usually occurs. On Yaxchilan Lintel 39 (Fig.1.12.), the serpent-like crea- 


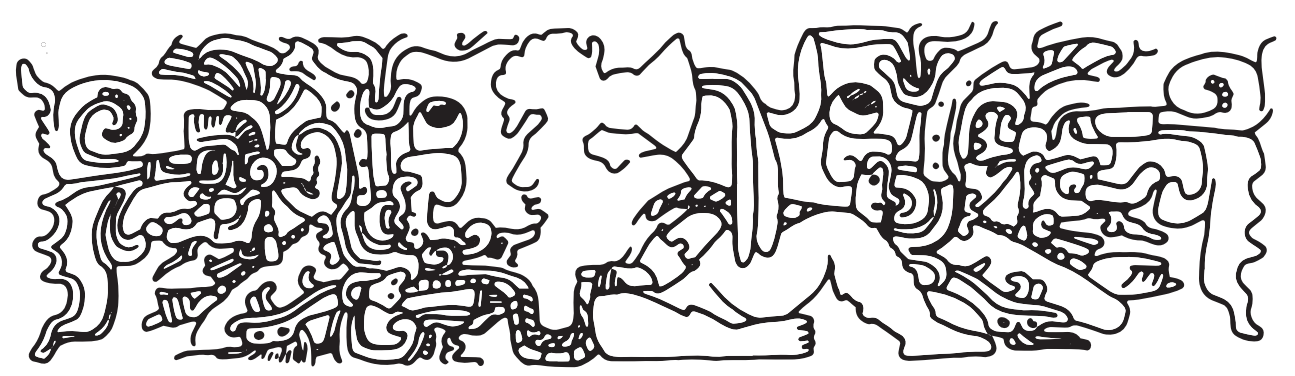

Fig.1.12.

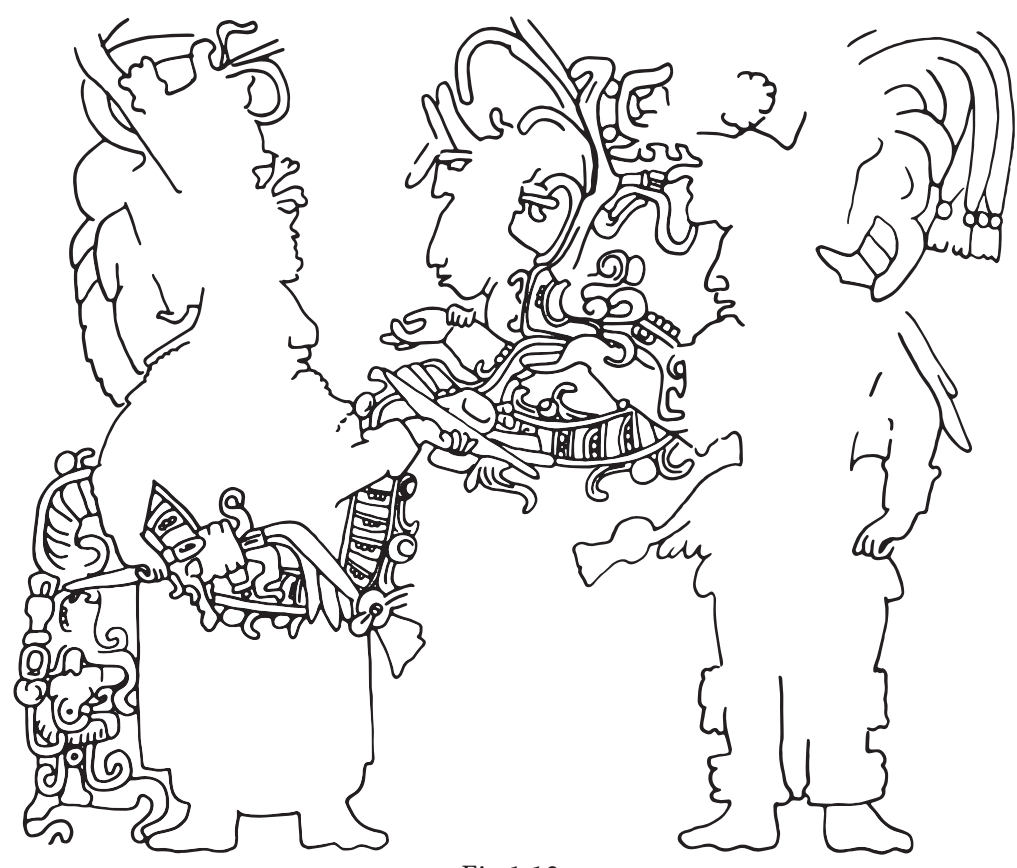

Fig.1.13.

ture, which is held by a human can be recognized as the centipede because of the bony maw and two fangs, but it has also some additional features, like the scrolls of fire coming through the corner of the mouth and beard, which indeed are more the features of snake/dragon creatures. The event is described as u-TZAK-(wa) K'AWIL -la - utzakaw K'awiil, "was conjured K'awiil" and is performed by the member of Yaxchilan dynasty. Indeed, from the maw of the centipede emerges the head of God $\mathrm{K}$ with a flaming torch piercing his forehead. The iconography of "conjuring K'awiil" was one of the main themes of Yaxchilan lintels, and the features of the centipede can also be traced to other pieces. Lintels 13 and 14 from Yaxchilan also represent the post-bloodletting event of a vision conjuring. The serpent-like creature from Lintel 13 is undoubtedly the centipede (Fig.1.13.). On Lintel 14 the creature has the segmented body, at least partially, and also small legs, but the maws are more like 
those of the snake. Additionally, the text on Lintel 14 refers to a creature as the way of the Ix Chak Cham and the name of the way is - K'AWIL K'AB-MUWAN? CHANNAL-la CHAK-ba-ya-ka-KAN, K'awiil K’ab Muwaan Chanal Chak Bay Kan, which situates it in the complex of K'awiil's snake avatar. This indeed might be a composite creature, "most of the creatures in Maya iconography with heads identified as centipede heads by Grube, Nahm, and Boot are more accurately conflations of different animals. Combining an imaginative centipede-like head with a snake or serpentine body is a common feature in Maya iconography" (Kettunen, Davis 2004:3). The "centiserpent" complex from Yaxchilan seems to be directly connected to K'awiil and vision contact. In this context, it also becomes related to the royal blood and power.

The other characteristic element of the representations of rulers is the so called ceremonial bar - "a central bar with two serpentine head at each end (..) constructed with two parallel and narrow bands joined by cross - strappings knotting or twined to create a segmented design" (Clancy, 1994: 7). From this instrument, the snake or dragon might be emerging, making it the tool for the vision and contact with the supernatural world. The ceremonial bar is considered royal insignia and a cosmological icon, the axis mundi because of the star motif often incorporated in it and the appearance of the double-headed serpent representing a portal. On Copan's stelas, the bar has the form of a bicephalic centipede, and is held in both arms of the ruler. The ceremonial bar in the form of the centipede-like skeletal creature seems to be a direct reference to the transition to the other world and appears as the device for contact with the gods. On Stela A, from the maws of centipede-like ceremonial bar emerges K'inich Ajaw. The connection between K'inich Ajaw and the centipede is well established in one of the god's names 7[Wuk] Chapat Tzikin K'inich Ajaw. At the same time, the centipede was presented as the channel of communication, like on the Lintels from Yaxchilan, and was incorporated into the symbol of royal power, that is, a ceremonial bar with the aspect of a Sun God.

\section{The skeletal maw of the centipede}

There are several images, where only the head or maw of a centipede is depicted. It can be easily recognized by its skeletal, bony look and two, long fangs, it also has a large eye covered with an eyelid, and occasionally a beard. Except for the characteristic protruding fangs, its bony appearance makes it a fantastical and extremely stylized creature. The maw of the centipede, wide opened, appears on a Pakal's sarcophagus lid, at the very bottom of the scene of king's afterlife journey, flanking the main image of the king (Fig.1.14.). Similar bony maw is a part of the Altar G at Copan, where the head of a centipede is paired with the head of a snake.

On Copan Stela 11, Yax Pasaj Chan Yopaat is standing on a stylized and simplified centipede maw - it is likely the postmortem image of a king erected as part of Temple 18 - the place of his burial (Grube, Martin 2008: 212). On Altar $\mathrm{U}$ from Copan, there is the image of two lords sitting on the teeth inside the opened 


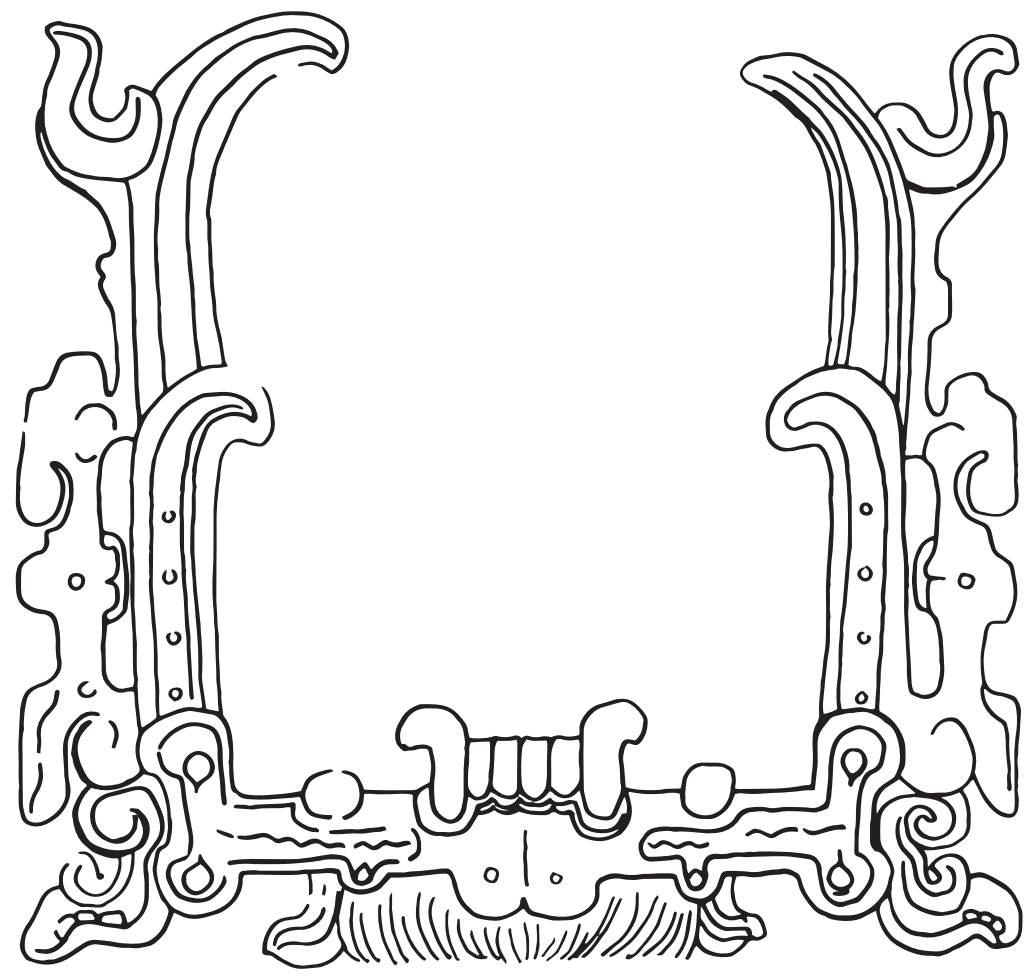

Fig.1.14.
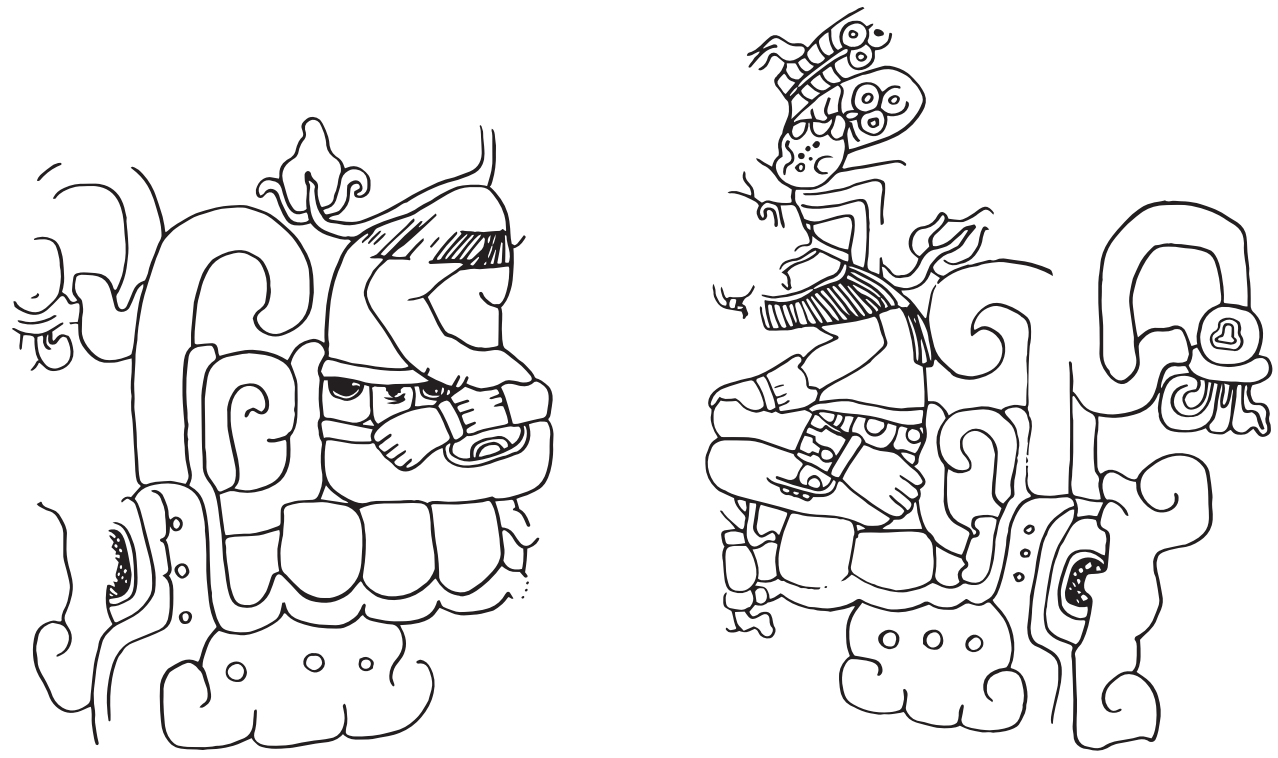

Fig.1.15. 
maw flanked by two fangs (Fig.1.15.), there are also images of people emerging from (or descending into) the maw of the centipede, like the person (probably a scribe holding a conch shell) in the detail of the structure 9n-82 at Copan or the eccentric flint in the shape of a man and centipede fangs (K7965).

These centipede-like creature's maws are generally understood as the iconographic trait of the Underworld - „In the Classic Maya thought, the entrance to the underworld was the devouring, venomous maw of the centipede" (Taube 2003: 416). This is not surprising, as the centipede, living in dark, humid places, is also a dangerous, venomous animal. When the character appears within or at the maw of a centipede, it can be recognized as entering into the Underworld, and it serves as the iconographic metaphor for death or less extreme contact with the otherworld. Centipede as the dragon-like, "centiserpent" fantastic creature was part of the "vision serpent" complex and way concept in general, serving as the channel of communication especially between K'awiil and the rulers. The extension of the perception of the centipede as a portal was done by using its maw as the pars pro toto visual metaphor for the entrance to the Underworld. This schematic and symbolical presentation of the fangs in the bony maw is also present in the script. As it was mentioned before, the T769a glyph is translated as the "hole, entrance", which corresponds with the appearance of the fangs in the iconography.

This Underworld aspect of the centipede might be also regarded in the opposition to the heavenly aspect of the snake, although the two are part of the same vision complex imagery. They both serve as the portal, but for quite different realms - "whereas the skeletal and venomous centipede maw indicated the threatening, deathly entrance to the underworld, the serpent commonly appears in scenes of celestial ascent" (Taube 2003: 437). This diversification could have an interesting impact on the interpretation of the scenes with vision serpents - those with the centipede, like previously mentioned Lintels from Yaxchilan, could have been the representations of summoning the being from the Underworld and those with the snake (like Lintel 15 from Yaxchilan) from the sky realm. This division, however, does not explain the cases of the conflation of the two animals - if their features were specifically underlined to imply the ambiguous nature of the vision and the conjured character or it was the way the artist wanted to manifest the ultimate visual metaphor for a portal, by mixing the symbols of sky and underground.

\section{Chapat and K'inich Ajaw - the solar aspect of the underworld creature}

K'inich Ajaw, literally the "Radiant Lord", is the name of a widespread deity with solar aspect, commonly called the Sun God, however it was not the only deity which could be connected with the Sun. The logogram - name of the K'inich Ajaw is the god's head with the k'in sign on the forehead, crossed eyes and T-shaped upper incisor. The name phrase connecting K'inich Ajaw with the centipede is 7[wuk]- CHAPAT-TZIKIN-K'INICH-AJAW - Wuk chapa[h] tzikin K'inich Ajaw - 

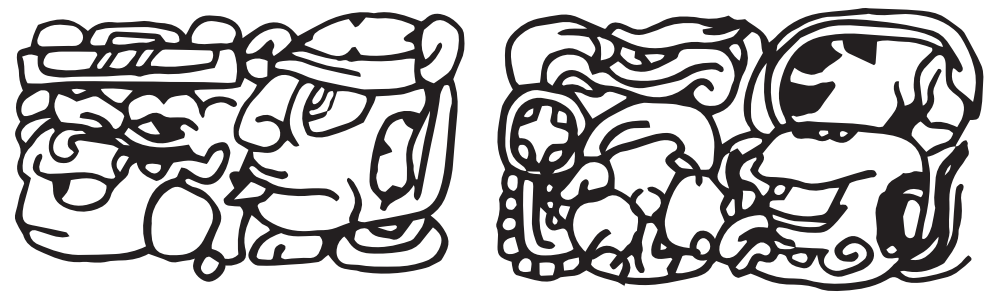

Fig.1.16.

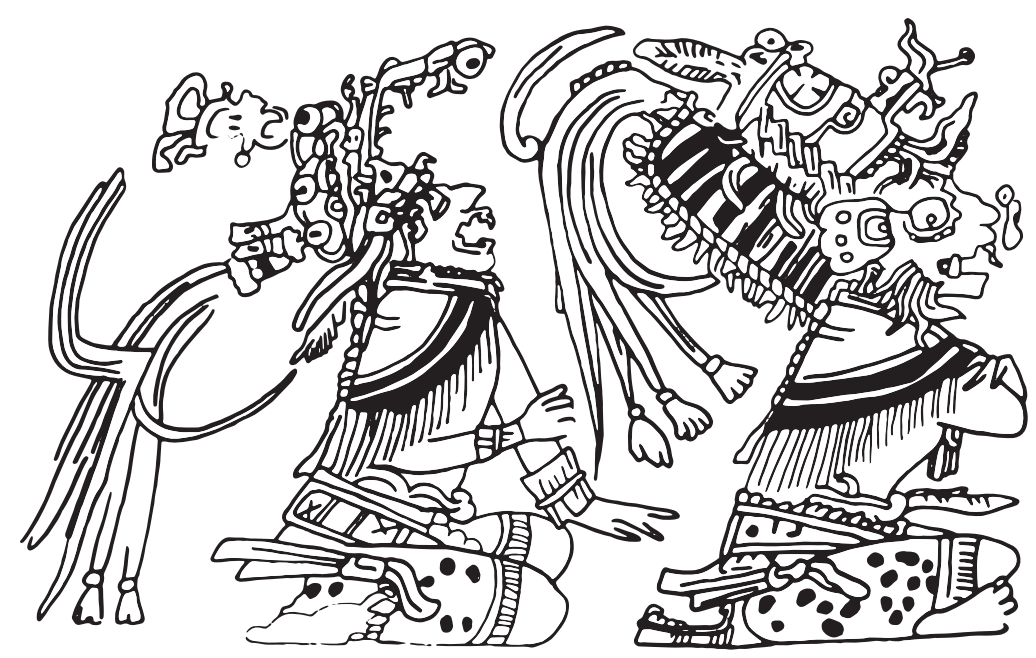

Fig.1.17.

this name was taken by the rulers acting as the Sun God and was also given as the name of stone monuments (Boot 2005). The second part of the name - represented by the lower glyph under the chapat sign, was first considered as a sign for CHAN - "snake". The recognition of a bird's head instead of a snake's led to a conclusion that the second part is the word TZIKIN - "bird" or "eagle" (Boot 2009), sometimes present - na phonetic complement suits both translations.

The whole title makes a specific connection between number seven, the centipede, the bird and the Sun God. The tzikin word might be just an allusion to some features of a bird - like feathers - "Based on the new transliteration of the above title as (U)huk Chapat Tz'ikin K'inich Ahaw it may be not so strange to find the centipede to be identified as a "feathered serpent or worm." The centipede not only is identified as a kind of "feathered serpent or worm," but also as a "fire serpent" (Tojolabal) (Boot 2005: 255). The image on vase K533, where this title/name appears in the Primary Standard Sequence, seems to connect these elements, as lords depicted there are dressed as jaguars but with fangs of a centipede and feathers in their headdresses. The whole phrase on vase K533 says $u$-b’a(h) ti akot-ah $u$-b'a(h) wuk-chapat-tzikin, -"(this is) his image in the dance as the image of Wuk Chapat Tzikin" (Boot 2005: 255). There, the name appears in the context of the ritual impersonation of a supernatural being celebrated by 

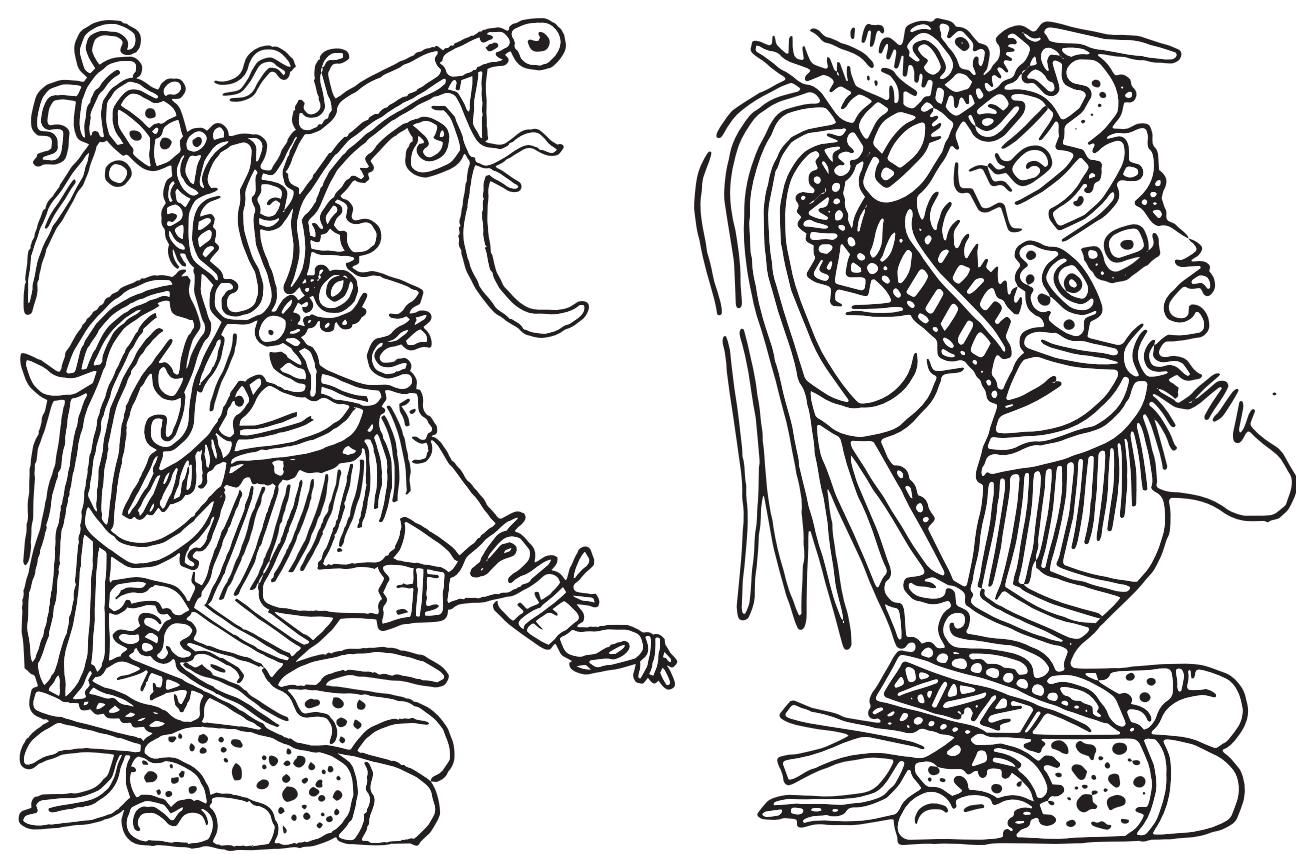

Fig.1.18.

dance, and the appearance of the jaguar feature in the costumes of impersonators provides the additional aspect of the Wuk Chapat identity. The animal outfits, moreover, might suggest that the lords are impersonating their wayob. The Wuk Chapat Tzikin name appears on vase K533 without the K'inich Ajaw sign, so it is possible that in this case it is a name of the way creature, not the solar deity. The Wuk Chapat Tzikin K'inich Ajaw appears on Stela A at Copan followed by a phrase K'uhul lakam Tuun "holy stela", implying that this is a name of the monument (Fig.1.16.). The naming of objects, especially naming them after supernatural, divine beings, is an example of the animistic beliefs among the Mayas.

The phrase introducing the owner of the vase as the impersonator of Wuk Chapat appears in the PSS on vases K2796 and K7750 - the Vase of Seven Gods and the Vase of Eleven Gods respectively. The iconography of both vases is similar and very interesting, as it might contain clues about the specific nature of gods connected to the centipede. On the Vase of Seven Gods, the God L sitting on a throne is receiving an audience from six gods, two of which wear centipede headdresses. The Underworld location is suggested by the death eye bar separating two levels of gods and is further underlined by the dark background of the vase. The date is 4 Ajaw 8 Kumku, none other than the very begging of the era - 13.0.0.0.0. The first assembly of gods witnessing this event is presented and, in the text, the gods are listed, beginning with Ik Akab Tan translated as Black His Dark Heart (Zender, Guenter 2003), which is likely a name of God L. In the list of gods also appears Bolon Yokte' K'uh - who often makes an appearance during the ending of time cycles and moments 
66 Monika Ciura

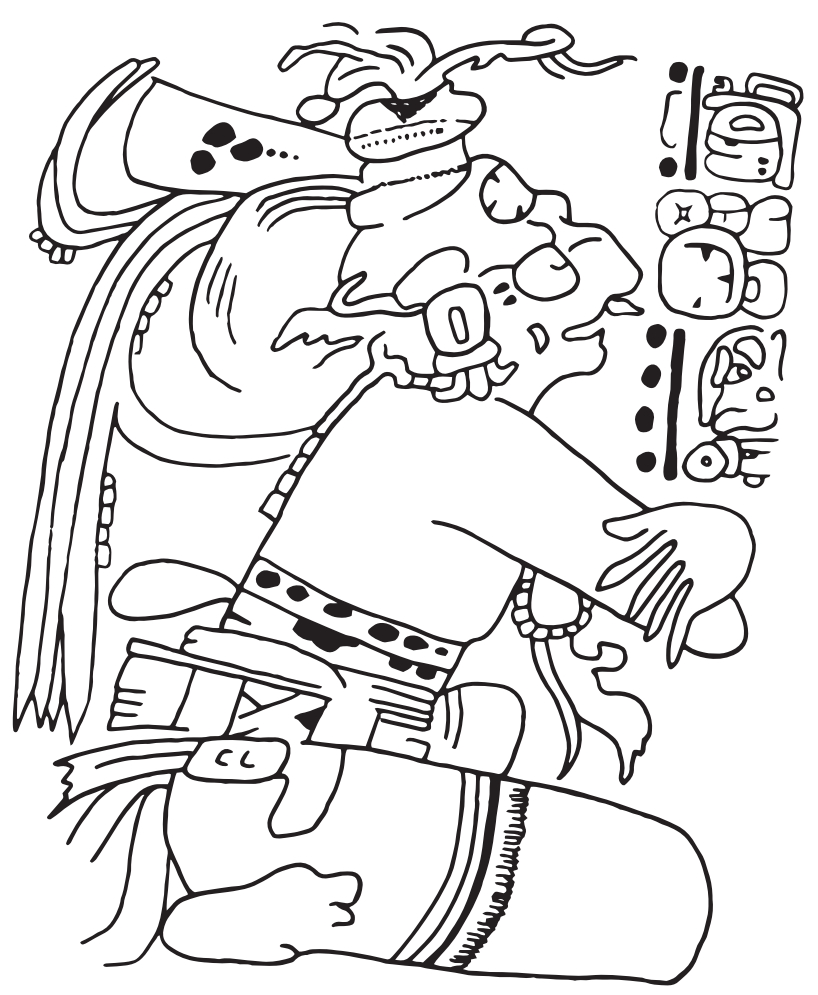

Fig.1.19.

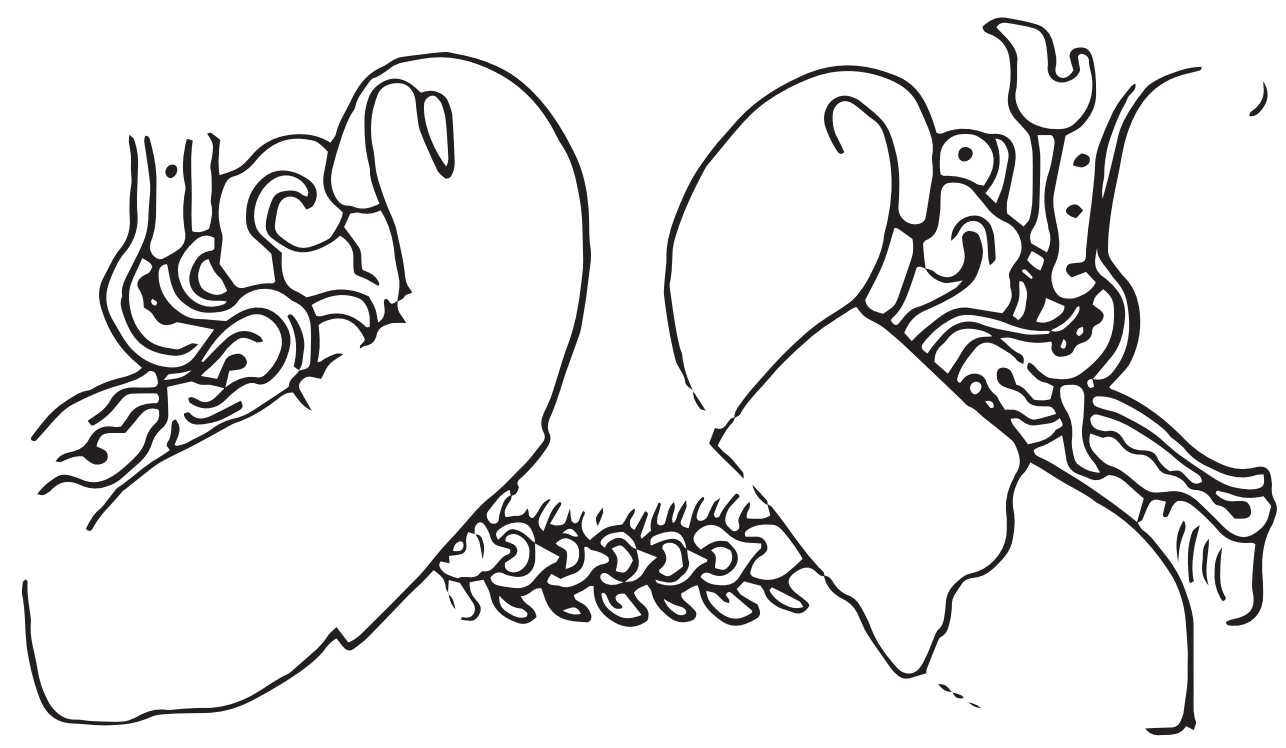

Fig.1.20. 
of transition. He is again mentioned on the Vase of Eleven Gods; therefore, we can assume that he would be depicted on both vases. The clues of the possible features and attributes of Bolon Yokte' K'uh are given on the unprovenanced stela from the Usamacinta region, presenting the image of a lord impersonating the Bolon Yokte' K'uh - "a rope is bound around his neck and one end dangles down, the headdress includes a large-fanged monster face that is delimited by a mat design" (Eberl, Prager 2005). It is also worth noting, that the lord depicted on this stela holds a spear with a stylized head of a centipede at both ends. The kind of the headdress described above is worn by a middle god from the lower register from the Vase of Seven Gods and the one before the last god in the upper register from the Vase of Eleven Gods (Fig.1.17, Fig. 1.18). Bolon Yokte' K'uh on these images also has a shell ear and a fish barbel. These two features happen to be characteristic of GI and these depictions are the evidence supporting the thesis about the unity of these two deities. On the Vase of Eleven Gods, the headdress of Bolon Yokte' K'uh is marked with a sign k'in, which also serves as an argument behind his identification with Nigh Sun and GI, who wears a "k'in bowl" as the headdress.

There is one especially interesting case of the appearance of Bolon Yokte' K'uh in the supernatural palace - this is on the God D Court Vessel described by Eric Boot (Boot 2008). The whole scene is taking place at the court of God D in a heavenly location marked by a Sky Band and it seems to be the gathering of both sky and earth (Underworld) gods - " jun pik chanal k'uh hun chan(?) kabal k'uh - (...) the numerous(?) Celestial/ Of the Sky Gods, the numerous(?) Earthy/Of the Earth Gods" (Boot 2008: 12). One of the gods in the upper register is named as ['u]7CHAPAT[TZ'IKIN] [K'IN]'AJAW-wa 9-['OKTE']K'UH - Uwuk Chapat Tz'ikin K'in[ich] Ajaw Bolon [y]okte' K'uh, which brings together two supernatural beings - Wuk Chapat and Bolon Yokte' K'uh. However, the image of the god lacks his characteristic headdress and a fish barbel, instead he has one tooth, k'in sign right on his forehead and on the top of his headdress Eric Boot spotted something resembling a centipede's maw (Boot 2008, Fig.1.19.). This feature actually resembles the image of the leftmost god from the lower register of the Vase of Seven Gods - therefore he could be a real representation of Wuk Chapat Tzikin K'inich Ajaw. What we see on the God D

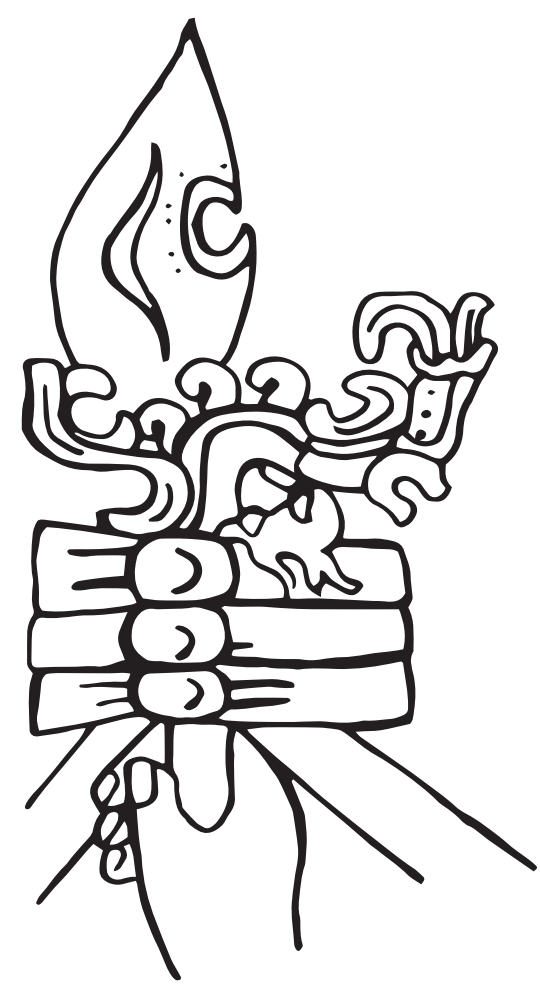

Fig.1.21. 
Court Vessel is conflation of two gods, which suggest the close connection between them, and this connection seems to be related to the Sun. The previously described image of the lord impersonating Bolon Yokte' Kuh with a spear with centipede's head might be the confirmation of this connection, so is the image on Stela 26 from Yaxchilan. There, the Itzamnaaj Bahlam is getting ready for war and receives the jaguar headdress from his wife. He has the features of Bolon Yokte' K'uh - the rope around the neck and the mat design on his buckler, and in the inscription his name comes after the name of Wuk Chapat K'inich Ajaw. It seems that he is impersonating Wuk Chapat K'inich Ajaw and at the same time wearing the attributes of Bolon Yokte' K'uh. The identification of GI with Bolon Yokte K'uh and his connection with the centipede might also be applied to the image from Stela I from Copan, where GI with all his characteristic attire, holds the centipede as the ceremonial bar (Stuart 2005, Fig.1.20.). I would say, with caution, that there is something resembling a rope surrounding his face. The solar aspect of this deity - the " $k$ 'in bowl" is more specifically connected with sunrise - as in the script, this is a sign meaning "east". The whole iconographic deity complex would therefore comprise - the G1 - the god with solar aspect connected with sunrise, the Bolon Yokte' K'uh - the god of war and transition and the Wuk Chapat Tzikin K'inich Ajaw - the aspect of the Sun God with some Underworld connotations due to the symbolism of the centipede. All of them could be manifestations of different aspects of one god or represent a closely bound group of supernatural beings.

There are few examples where the centipede is directly interacting with K'inich Ajaw, the Sun God and the association with the Night Sun or the rising Sun seems to be specific to this animal.

A fine example of the role of the centipede with the connection to the Sun God is represented on Yaxchilan Hieroglyphic Stairway 3 - here, the K'inich Ajaw with the centipede headdress is depicted inside the belly of a crocodile, which stands as a visual metaphor for the Earth or the night sky. There is, however, another figure with a "k'in bowl" headdress emerging from the behind of the crocodile. David Stuart pointed out, that this could be a reference to G1 and the solar aspect of this deity - "Starry Deer Crocodile likely served as the symbol for the night or underworld sky, and I believe an argument can be made, that the k'in bowl was its "anus", whence the sun would daily rise in the east" (Stuart 2005: 168). The whole image might be the representation of the Sun's journey, first, during the night, it stays in the Underworld, which is suggested by the centipede headdress, and then at dawn it leaves the Underground as the G1.

Another thing that connects the features of a centipede with the Sun are solar cartouches, which tend to have two stylized, curved fangs belonging to the centipede in the rim corners. These cartouches are framing mirrors, solar motifs and images of the ancestors in the guise of the Sun God (Steinbach 2015: 61). Additionally, on Yaxchilan Stela 1, there is the image of a person with the k'in sign on the headdress holding the ceremonial bar tipped with chapat maws. He is surrounded 


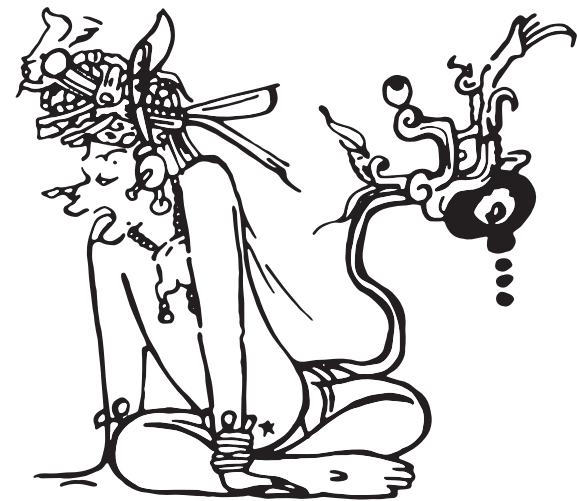

Fig.1.22.

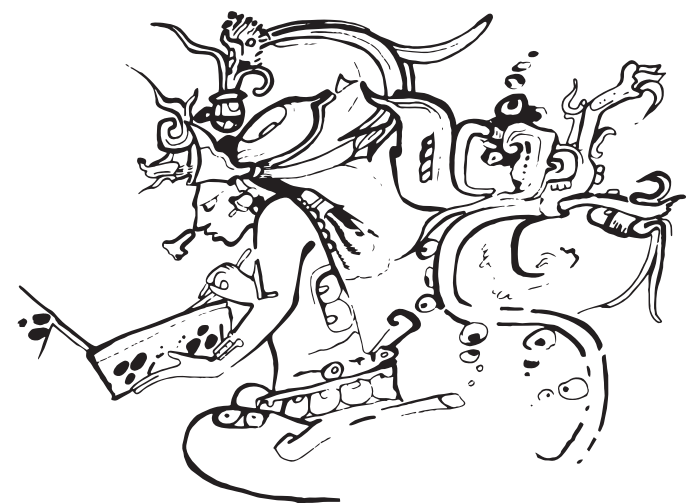

Fig.1.23.

by the cartouche with the centipede fangs in four corners, but the cartouche additionally has a motif of several dots on the bottom, which makes it similar to the T683 sign representing a moon crescent. Both symbols are symbolizing points of passage and the journey of the celestial bodies through the night and the Underworld.

Although the whole name - Wuk Chapat Tzikin K'inich Ajaw seems to be reflecting the composite nature of the deity bearing it, stressing its connection with the Sun, the first numerical part is definitely creating some additional meaning. Eric Boot suggested that number 7 has a special connection to warfare (Boot 2005: 250). The centipede is also present in war imagery, which might be due to the con-

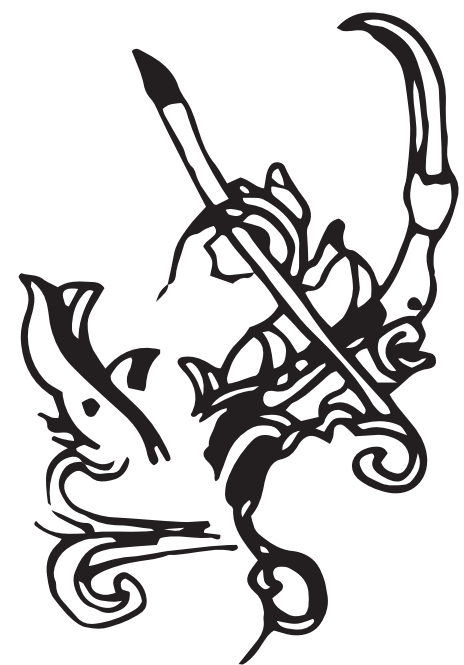

Fig.1.24. nection of Wuk Chapat with Bolon Yokte' K'uh, as we have seen that this god or his features tend to appear in a war context. The lord impersonating Bolon Yokte K'uh on the previously mentioned stela is holding a large spear with the centipede head on the edge (Fig.1.21.). Similar spear is held by the lord on Naranjo Stela 8. Number seven seems to be connected with the centipede also in the Postclassic Period, and even later, that is why Eric Boot identified Wuk Chapat with the war serpent and the Postclassic god K'uk'ulkan "Feathered Serpent" - "If correct, in the Classic period there was a war-related deity with the name (U)huk Chapat Tz'ikin K'inich Ahaw (...) This deity may be the or a Classic Maya precursor of the Postclassic Quetzalcoatl or K'uk'ulkán "Feathered Serpent. (...)". (Boot 2005: 259). The appearance of number seven in the name of a centipede is peculiar, also because there is an entity named sak baak nah chapat where nah is commonly translated as "house" but its meaning 
could also be "first". This could be some word game giving us a pair of centipede-like beings named "first" and "seven", which was common in naming pairs of gods in Popol Vuh (Grofe 2009), where there is One Hunahpu and Seven Hunahpu and One Death and Seven Death. It would also be convenient in the identification of Wuk Chapat with GI and sak baak nah chapat with GIII; however, because of the frugal iconographic evidence such identification may only be suggested.

At first sight, the relation of the centipede to solar aspects appears surprising, but it might be interpreted as the night aspect of the Sun, rising from the Underworld as the day begins, and sinking into it as the day ends. The Wuk Chapat K'inich Ajaw is the Underworld deity connecting the dark, wet and dangerous aspects of the centipede with the bright/hot aspects of the Sun, and clearly these two oppositions meet during dawn and dusk. There is also a case of conflating the Wuk Chapat name with the name of the god of transition and war - Bolon Yokte K'uh, who sometimes merges with a G1 - the god related to the rising Sun. It seems that every deity connected with a centipede by name or by imagery, is the deity of the passage, especially the passage between day and night and underground and aboveground.

\section{Centipede and scribes}

Among the contexts of appearance of the centipede, there is also one connected with scribes and artists (Taube, 2003). A fine example is the hand with a brush emerging from a skeletal maw, depicted on the carved bone from the Burial 116 at Tikal (1.24.).

There are also images of divine, monkey patrons of scribes with tails transforming into centipedes with the characteristic maws at the end. This is clear on vase K8240, where the Monkey-Man scribe on the throne is receiving homage and offerings from three characters sitting in front of him (Fig.1.22.). There are also scenes involving supernatural scribes engaged in writing activities - on vase K1523 two scribes are sitting with the codices in their hands, and the centipede-like creature is arising between them (Fig.1.23.). The scribes have Akbal body markings and one of them has the "print-out" icon with bars and dots numbers emerging from behind his back. The maw of the serpent animal bears resemblance to the centipede ones, but the beard and the maize leaf ear make it a fantastic, composite, dragon-like creature. The death eyes and black water droplets are attached to its body, possibly making it an Underworld way creature. The image on vase K4010 displays another detail of this centipede-like being; the serpent emerges from the beak of a bird's head located near the old scribe holding a conch shell (Fig.1.25.). The bird head recalls the name of the aforementioned supernatural being - Wuk Chapat Tzikin K'inich Ajaw. The body of the scribe is marked with the Akbal signs, in contrast to the second character of this scene, who is clearly a human lord, and who also holds a conch shell. Although the body of the serpent is highly stylized, two curved fangs are visible at its end, and the death eyes and black water droplets are attached to its 


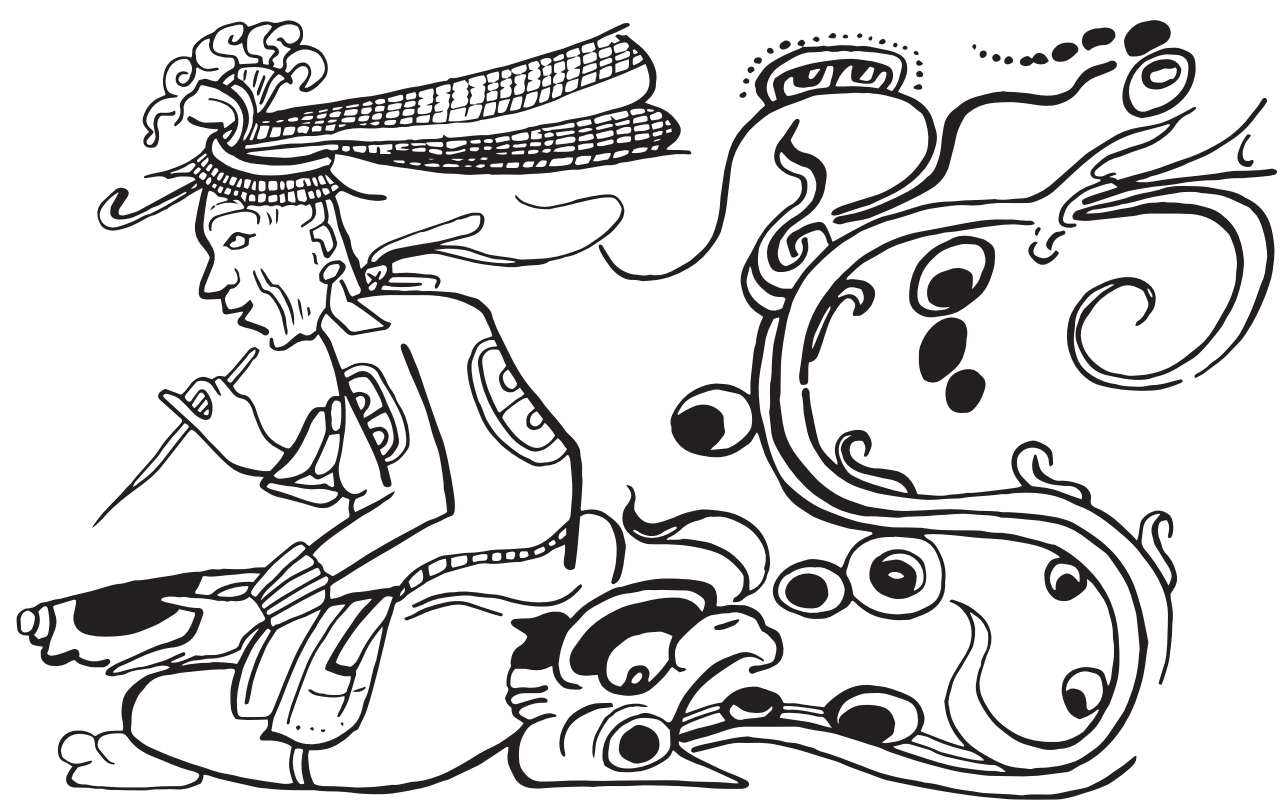

Fig.1.25.

body like on the previously mentioned pieces. There is another analogical scene depicted on vase K8425. The centipede's appearance with the scribes with "darkness" signs on their bodies is additionally confirming their Underworld provenience. It is also possible that the centipede was considered the way companion of the scribes, especially those supernatural ones. The writhing body of the centipede with thin lines coming out of it resembles a plant with young sprigs and stalks - the floral and vegetative imagery was often incorporated into the images of scribes, on their headdresses and clothing. This is a characteristic feature of Maya art - the similarities were used in constructing symbolic, visual layers of the image.

Quite an intriguing scene including dragonish centipede is depicted on vase K511. There, in the supernatural palace of the God L, he ties a bracelet on a women's wrist and in front of the throne there is a gathering of three characters. One is about to chop off the head of the other with an axe. The sacrificed person is sitting on the ground, but there is something emerging from behind his legs - a creature very similar to the centipede connected with the scribes - with a leaf ear and death eyes. What is most striking, is that the centipede is looking like it is attacking the third character involved in this scene - he is however standing still and patiently holding an ax in his hand. The creature emerging from the victim is interpreted as his way, escaping the body of the dying owner and making the last effort to protect him (Velasquez 2009: 10).

The interesting case of conflation of the monkey, scribes and centipede is the full figure variant of K'in - "day" sign on Yaxchilan Lintel 48 (Fig.1.26.). Here, the monkey has a centipede tail and seems to be connected to the count of days and 


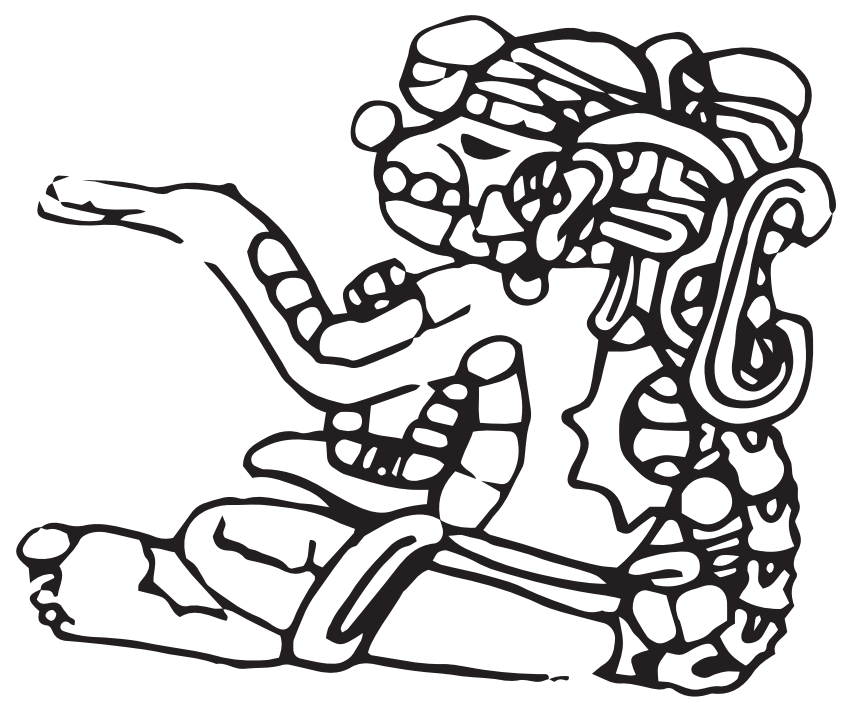

Fig .1.26.

the Sun - "The K'in variant monkey may represent a count of days beginning at dusk, the time that the monkey's sun shines, according to Tzotzil Maya" (Milbrath 1999). Another image of the monkey with a centipede tail forming a variant of the $k^{\prime}$ in sign can be found on Copan Stela D. If the monkey $k$ 'in variant was connected to the twilight also in the Classic times, it would complement the understanding of the Wuk Chapat as the aspect of the Sun from the border between night and day, partially belonging to the Underworld. The monkey-centipede conflation in relation to the Sun could also affect the concept of divine monkey scribes and scribes in general. The appearance of the centipede in relation to scribes might also imply that their special knowledge connected them with the supernatural realm.

\section{Centipede in sources from Postclassic Period to modern times}

The centipede in Maya codices was recognized by Alfred Tozzer. He saw the glyph associated with God D, Itzmana - the Akbal sign in a dotted circle - as the sign for a centipede (Tozzer 1910: 304). The Akbal sign with a dotted part is more likely the representation of a feathered headband, which is part of the name of Itzamna, visible also on the Classic period imagery. More accurate centipede's maws form the headdress of the death god - God A on Dresden, page 13a. There are two fangs at the extension of the jaw and two antennae. Therefore, the possible appearance of a centipede motif in codices is connected with death.

In the "Ritual of Bacabs", there is an echo of the Wuk Chapat in the incantation for ulcers, number XV (Roys 1965). The name of the demon responsible for that particular ailment is kak-tamay-monster, kan-ne-chapat - "fire tailed centipede" and uuc-ne-chapat - "seven tailed centipede". Again, there is a connection to number 
seven, centipede and the fiery aspect, that could have been the effect of the solar affiliation of the centipede in the Classic times. Additionally, the creator of this illness is introduced as Kin Chak Ajau Kolop u uich kin - "Sun great lord, wounder of the eye of the Sun". The appearance of the centipede in this incantation was the basis of assumption that the sak baak nah chapat and all of the possible way creatures with k'ak part in their names, were indeed connected to the power of inflicting ulcers or other illnesses connected with burning and inflammation (Helmke, Nielsen, 2009: 65). The existence of the entity called uuc chapat in the XVIII century was definitely the effect of a deep-rooted memory of the Underworld deity with solar aspects. A similar name appears in "Book of Chilam Balam of Tizimi", where there is mention of Aj Wuk Chapat (Boot, 2005), and in the song from "Cantares de Dzitbalche" referring to Kukulkan there is mention of a character called " $\mathrm{X}$ Ah Chapat que tenia junto siete cabezas" (Boot 2005).

All of the Colonial and modern sources refer to the centipede as connected to fire and/or number seven, which is definitely not coincidental. The memory of Wuk Chapat survived in recognizing the centipede as a dark and dangerous creature.

\section{Summary and conclusions}

Centipede in its realistic form appears very rarely in Maya art. In the Olmec and Early Classic times it was depicted as a bicefalic, segmented animal with trifoil mouth, and later evolved into a fantastic, skeletal, enormous creature. Only two protruding fangs and segmented body were left to draw resemblance to the real arthropod. In the imagery of this centipede-like creature there is a visible influence of the imagery of the snake, and those two species are conflating with each other. With the addition of the definitely fantastical features, like a beard and scrolls of fire, a centipede constitutes the dragon creature serving as the portal and passage between realms. As one of the way creatures, the centipede was connected with K'awiil and visions, as it appears in the scenes of conjuring the god through the skeletal, centipede-like maws on Lintel 39 from Yaxchilan. It might have been considered as part of the "vision serpent" or "vision dragon" complex, being the portal, the channel of transition between realms. The centipede called sak baak nah chapat was also a way being connected with Palenque and its patron god GIII, as it appears as one of his names at the moment of his birth described on the Tablet from the Temple of the Sun. Sak baak nah chapat was also one of the major agents during the mythological event happening on 13 Ok 18 Wo, described on Tablet from Temple XIV at Palenque. There, the centipede is introduced as the way of K'awiil and the event seems to be the "nine times strengthening" of the sak baak nah chapat connected with the first accession of Bolon Yokte K'uh. Sak baak nah chapat was the name of a way creature belonging to gods who legitimized the power of Palenque dynasty, especially the GIII, and to the dynasty itself. The maws of the centipede appear also in the arrangements, suggesting that they were the symbol of the entrance or the portal to the Underworld. Another context bringing a lot to the understand- 
ing of the meaning of the centipede-like creatures in Maya art is connected with the solar aspects, especially the concept of the Sun's night journey through the Underworld, and its emergence at sunrise. The supernatural character Wuk Chapat Tzikin K'inich Ajaw was likely impersonated by rulers and had a special connection with Bolon Yokte' K'uh, the Underworld deity of transition and war, likely identified as the Night Sun and GI. The concept of the Sun, which during the night transformed into an Underworld deity with centipede aspects, might be confirmed by the scene form Hieroglyphic Stairway from Yaxchilan, where the Sun God with a centipede headdress is depicted inside the crocodile-earth, and the god with a "k'in bowl" headdress (likely G1) is emerging through its anus. There is also another context confirming the connection of the centipede with the Sun's transition. The monkey, full-figure sign for k'in, "day" in Long Count, has a centipede tail in two cases. The connection between the monkey and the centipede was expanded in the imagery of the supernatural scribes, who due to the mythological story were also sometimes presented as monkeys.

The connection between the centipede and the Underworld seems to be based on the observations of the natural habitat of the animal. Centipedes live in dark, wet places, like caves and shadowy structures. These kinds of locations, caves especially, were considered the entrances to the supernatural, underground realm, so the animals living there were supposed to be living in liminal spaces. Such an animal was likely an inhabitant of both realms, and therefore the symbol of the passage and portal. The time of the centipede's activity also marks the sphere of the boundary of day and night. Perhaps because of that, it was considered connected with the rising and disappearing of the Sun in the dark realm of the night. As a way creature, the centipede might have become the evil spirit with the power to inflict ulcers. Being the creature of the liminal spheres, it was a symbol of the passage of the Sun through the Underworld, closely connected with sunrise and sunset and transition in general.

\section{Bibliography}

Barrera Vásquez, Alfredo

1993 Diccionario Maya. Maya-Español, Español-Maya $3^{\text {rd }}$ edition, Mexico City: Editorial Porrua

Beliaev, Dimitri, Davletshin Albert

2006

Los sujetos novelísticos y las palabras obscenas: los mitos, los cuentos y las anécdotas en los textos mayas sobre la cerámica del Periodo Clásico. In: Sacred books, Sacred languages. Two Thousand Years of Ritual and Religious Maya Literature, pp. 21-44, Edited by R. Valencia y G. Le Fort, Markt Schwaben, Alemania: Verlag Anton Saurwein (Acta Mesoamericana, 18) 
Boot, Eric

2004

Vocabulary in the Cholti' Language: A Transcription of the „Bocabulario Grande" by Fray Francisco Moran (1695), [online] Available at: http:// www.famsi.org/mayawriting/dictionary/boot/cholti_moran1695_revised.pdf

2005 Continuity and Change in Text and Image at Chichen Itza, Yucatan, Mexico: A Study of the Inscriptions, Iconography and Architecture of the Late Classic to Early Postclassic Maya Site. CNWS Publications 135, Research School CNWS, Leide

2008 At the Court of Itzam Nah Yax Kokaj Mut: Preliminary Iconographic and Epigraphic Analysis of a Late Classic Vessel. [online] Available at: : http://www.mayavase.com/God-D-Court-Vessel.pdf

2009 The Updated Preliminary Classic Maya-English, English-Classic Maya Vocabulary of Hieroglyphic Readings. Mesoweb resources, [online] Available at: http://www.mesoweb.com/resources/vocabulary/VocabClancy, Flora S. ulary-2009.01.pdf

1994 The Classic Maya Ceremonial Bar. Anales del Instituto de Investigaciones Estéticas, [S.1.], p. pp. 7-45, [online] Available on: http://www. analesiie.unam.mx/index.php /analesiie/article/view/1709>

Coe, Michael D., Justin Kerr

1997 The Art of the Maya Scribe. New York: Harry N. Abrams.

Capinera, John L.

1993 Insects in Art and Religion: The American Southwest, In: American Entomologist, 39 (4).

Eberl, Markus, Prager, Christian

2005 B'olon Yokte' K'uh: Maya conceptions of war, conflict, and the underworld. In: Wars and Conflicts in Prehispanic Mesoamerica and the Andes: Selected Proceedings of the Conference Organized by the Société des Américanistes de Belgique with the Collaboration of Wayeb (European Association of Mayanists), Brussels, 16-17 November 2002, Edited by Peter Eeckhout and Geneviève Le Fort, British Archaeological Reports International Series, no. 1385. Oxford, UK: John and Erika Hedges Ltd.

Freidel, David, Linda Schele, and Joy Parker

1993 Maya Cosmos: Three Thousand Years on the Shaman's Path. WilliamMorrow, New York.

Guenter, Stanley

2007 On the Emblem Glyph of El Peru. In: The PARI Journal VIII(2).

Grofe. Michael J.

2009 The Name of God L : B'olon Yokte' K’uh?, In: Wayeb Notes, No. 30 
Gronemeyer, Sven, MacLeod Barbara

2010 What could happen in 2012: a re-analysis of the 13- bak'tun prophecy on tortuguero monument 6, In: Wayeb Notes, No. 34

Grube, Nikolai, Nahm Werner

1994 A census of Xibalba: A complete inventory of way characters on Maya ceramics. In: The Maya Vase Book Volume 4. pp. 686-715. Kerr Associates Helmke Christopher, Nielsen Jesper

2009 Hidden Identity \& Power in Ancient Mesoamerica: Supernatural Alter Egos as Personified Diseases. In: Acta Americana,17(2).

Hogue, Charles Leonard

1991 Latin American Insects and Entomology, University of California Press Hull, Kerry, Carrasco, Michael and Wald, Robert

2009 The First-Person Singular Independent Pronoun in Classic Ch'olan. In: Mexicon, vol. XXXI, no. 2, pp. 36-43

Jarrar Bashir M.

2010 Morfología, Histología e Histoquímica del Aparato Venenoso del Ciempiés, Scolopendra valida (Chilopoda, Scolopendridae). In:. J. Morphol., vol.28, n.1, pp.19-25. [online] Available at: <http://www.scielo.cl/scielo.php?script=sci_arttext\&pid=S0717-95022010000100003-

Kaufman, Terrence \&lng $=$ es\&nrm $=$ iso >

2003 A Preliminary Mayan Etymological Dictionary, ,[online] Available at: $<$ http://www.famsi.org/reports >

Kettunen, Harri and Davis II, Bon, V.

2004 Snakes, Centipedes, Snakepedes and Centiserpents : Conflation of liminal species in Maya iconography and ethnozoology, In: Wayeb Notes, No. 9

Milbrath, Susan

1999 Star Gods of the Maya: Astronomy in Art, Folklore, and Calendars. Austin: University of Texas Press, Project MUSE

Montgomery, John, Helmke, Christopher

2007 Dictionary of Maya Hieroglyphs, [online] Available at: http://www.famsi.org/mayawriting/dictionary.htm

Prager, Christian

2011 Is T911 a Logograph for AS or ASUL "Locust, Grasshopper", [online] Available at https://www.academia.edu/4778826/Is_T911_a_logoRoys, Ralph, L. graph_for_AS_or_ASUL_locust_grasshoper

1933 The Book of Chilam Balam of Chumayel. Washington D.C.; Carnegie Institution

1965 Ritual of the Bocabs, The Civilization of the American Indian Series, Vol. 771, Norman: University of Oklahoma Press 
Steinbach, Penny J.

2015 Sacrificing the Jaguar Baby: Understanding a Classic Maya Myth on Codex-style Pottery, Thesis, The University of Texas at Austin

Stuart, David

2005 The Inscriptions from Temple XIX. A Commentary, The Pre-Columbian Art Research Institute

Taube, Karl

2003 Maws of heaven and hell: The symbolism of the centipede and serpent in Classic Maya religion, In: Antropologia de la Eternidad: La Muerte Tozzer, Alfred M. en la Cultura Maya, Sociedad Espanola de Estudios Mayos

1910 Animal figures in the Maya codices. Cambridge, Mass.: Published by the Museum.

Velásquez Garcia, Erik

2009 Reflections on the Codex Style and the Princeton Vessel, In: The PARI Journal, Volume X, No. 1

Viveiros de Castro, Eduardo

1992 From the enemy's point of view: Humanity and divinity in an Amazonian society, Chicago: University of Chicago Press

Wagner Elisabeth, Gronemeyer Sven, Prager Christian

2015 Tz'atz' Nah, a "New” Term in the Classic Mayan Lexicon, In: Textdatenbank und Wörterbuch des Klassischen Maya

Zender, Marc, Guenter Stanley

2003 The Names of the Lords of Xib'alb'a in the Maya Hieroglyphic Script. In: Sistematización de los Estudios Americanistas y sus Repercusiones. Edited by Hanffstengel, R. ., \& Tercero, V. C. Eduard y Caecilie Seler, D.F: Facultad de Filosofía y Letras, Universidad Nacional Autónoma de México. 
